\title{
Entre el cielo y el infierno: cofradías de indios en el Cusco y el programa iconográfico de las postrimerías (siglos XVI y XVII)
}

\section{Between heaven and hell: confraternities of indians in Cusco and the iconographic program of postrimerías (16th and 17th Centuries)}

Paula Martínez Sagredo ${ }^{1}$ https://orcid.org/0000-0002-7881-3859

Alberto Díaz Araya ${ }^{2}$ https://orcid.org/0000-0001-5080-1672

${ }^{1}$ Universidad de Tarapacá, Departamento de Ciencias Históricas y Geográficas, Avda. 18 de Septiembre 2222. Arica, CHILE. Email: pmartinezsagredo@gmail.com.

${ }^{2}$ Universidad de Tarapacá, Departamento de Ciencias Históricas y Geográficas, Avda. 18 de Septiembre 2222. Arica, CHILE. Email: nortealberto@hotmail.com

\section{Resumen}

En el presente trabajo se propone una línea de investigación que aúna los documentos históricos con los visuales en pro de explicar la profusión y vigencia, a través de los siglos, de distintos programas iconográficos en la zona del Obispado del Cusco colonial. Se revisarán las características de la pintura mural asociada al contexto evangelizador, para finalmente indagar sobre el vínculo que existió entre dos tipos específicos de cofradías de naturales durante la Colonia y la vigorosidad de una serie recurrente de temas evangelizadores como el cielo y el infierno, característicos del barroco andino.

Palabras claves: pintura andina, evangelización, cofradías, indígenas, Cusco, Colonia.

\begin{abstract}
In this paper we propose a line of research that joins historical and visual documents in order to explain the profusion and validity throughout centuries of several different iconographic programs in the archdiocese of Colonial Cusco. Some characteristics of mural painting associated to evangelizing contexts will be analyzed, as well as the link that existed between two specific types of indigenous confraternities in Colonial times, and the vigor of a recurring series of evangelization topics, such as heaven and hell, proper of the Andean baroque.
\end{abstract}

Keywords: Andean painting, evangelization, confraternities, indigenous peoples, Cusco, Colonial period. 


\section{Introducción}

La imaginería religiosa, dentro del proyecto evangelizador, cumplió varios roles. Por un lado, sirvió como apoyo visual en la transmisión de los textos catequéticos, constituyéndose un programa pictográfico que estaba fuertemente asociado a las narrativas católicas. Por otro, formó parte de los oficios que fueron enseñados a la población indígena dentro del mismo proyecto evangelizador que se consideraba ayudaría a los naturales a entrar en la "buena policía y costumbres", como parte del proceso de convertirse en vasallos del Rey, bajo determinados patrones de conducta en la formación de la feligresía indígena (Cohen, 2011; Martínez, P., 2014). En algunos casos estos planos o roles coincidieron, como por ejemplo, en la ornamentación de las capillas donde los mismos indígenas -que ya habían aprendido el oficio de pintores, tal como lo detalla Guaman Poma (1615, p. 673 [687])- eran quienes pintaban las imágenes que luego servirían para catequizar a sus congéneres al integrarse al repertorio de homilías como parte de la representación visual y estética que los sermones contenían (Cohen, 2011; Martínez, 2014) (Figura 1). En el presente artículo exploraremos la vinculación entre el auge de motivos y temas específicos dentro de la imaginería evangelizadora con la proliferación de algunas cofradías puntuales, como la del Santísimo Sacramento y la de las Ánimas del Purgatorio. No queremos, empero, inducir al lector a pensar que esta iconografía es propia y única de esta región, pues responde más bien a un proceso de gran extensión geográfica que incluye importantes ciudades de los virreinatos así como del resto del mundo cristiano de la época. Desgraciadamente, por restricciones de espacio tampoco podemos en las siguientes páginas identificar las peculiaridades iconográficas propias del mundo andino en ese arte, sino simplemente recorrer los vínculos entre la iconografía de la zona y la agencia de las cofradías en la proliferación de este panorama iconográfico.

\section{La imaginería religiosa}

El desarrollo de la pintura en el Nuevo Mundo estuvo fuertemente determinado por la evangelización, por la necesidad de imágenes que las nuevas colo- nias presentaban, especialmente aquellas de culto, aunque también se puso acento en proveer las condiciones para su producción dentro de los nuevos contextos. En este plano, los distintos virreinatos generaron principalmente tres formas para abastecerse de la imaginería requerida. Por una parte, las importaciones, que cumplieron asimismo el rol de servir de fuente de copia y de inspiración; luego, a través de la formación de indígenas en oficios cuya especificidad muchas veces estuvo marcada por las distintas predilecciones o fundamentaciones de cada orden religiosa y, finalmente, a través de la inmigración de pintores europeos (Bargellini, 2007). En cuanto a la enseńanza de oficios ${ }^{1}$ que las distintas órdenes ofrecían, los frailes franciscanos fueron los pioneros en establecer escuelas para enseñar a los indígenas conversos, especialmente en México y Quito (Webster, 2014). Sin embargo, la metodología que aplicaron estos religiosos fue luego adoptada también por las otras órdenes, como la jesuita en la región andina. ${ }^{2}$

La pintura evangelizadora colonial tiene sus inicios en los complejos monásticos de México, que conservaban una fuerte base indígena fundamentada en el tradicional colectivismo agrario, donde la mano de obra autóctona se combinaba con la dirección de los monjes, quienes diseñaron para toda Nueva España monasterios diferentes a los de los españoles. Así, las

1 Un ejemplo de la protección que recibieron los naturales en el aprendizaje de los oficios es la noticia que nos entrega Esquivel y Navia del 5 de septiembre de 1559, donde "a pedimento de los indios de Acomayo, para que el corregidor y justicias del Cuzco no consientan recoger a los indios que en esta ciudad estuviesen aprendiendo oficio, y que los dejen residir donde quisieren pagando sus tributos" (Esquivel y Navia, 1980, p. 206).

2 En 1524 fray Pedro Gante, educado en las artes y armado de grabados europeos, establece en la Ciudad de México la primera escuela de este tipo en San José de los Naturales. Asimismo, los agustinos fundaron escuelas similares en Nueva España, mientras que en Quito los franciscanos iniciaron en su monasterio el entrenamiento artístico de indígenas desde 1535 . A pesar de que en el virreinato peruano la Orden con mayor importancia es la jesuita, en el territorio cusqueño los franciscanos ejercieron una influencia considerable, que es palpable, por ejemplo, a través del legado textual y visual dejado por Juan Pérez de Bocanegra (véase Mannheim, 2012). 

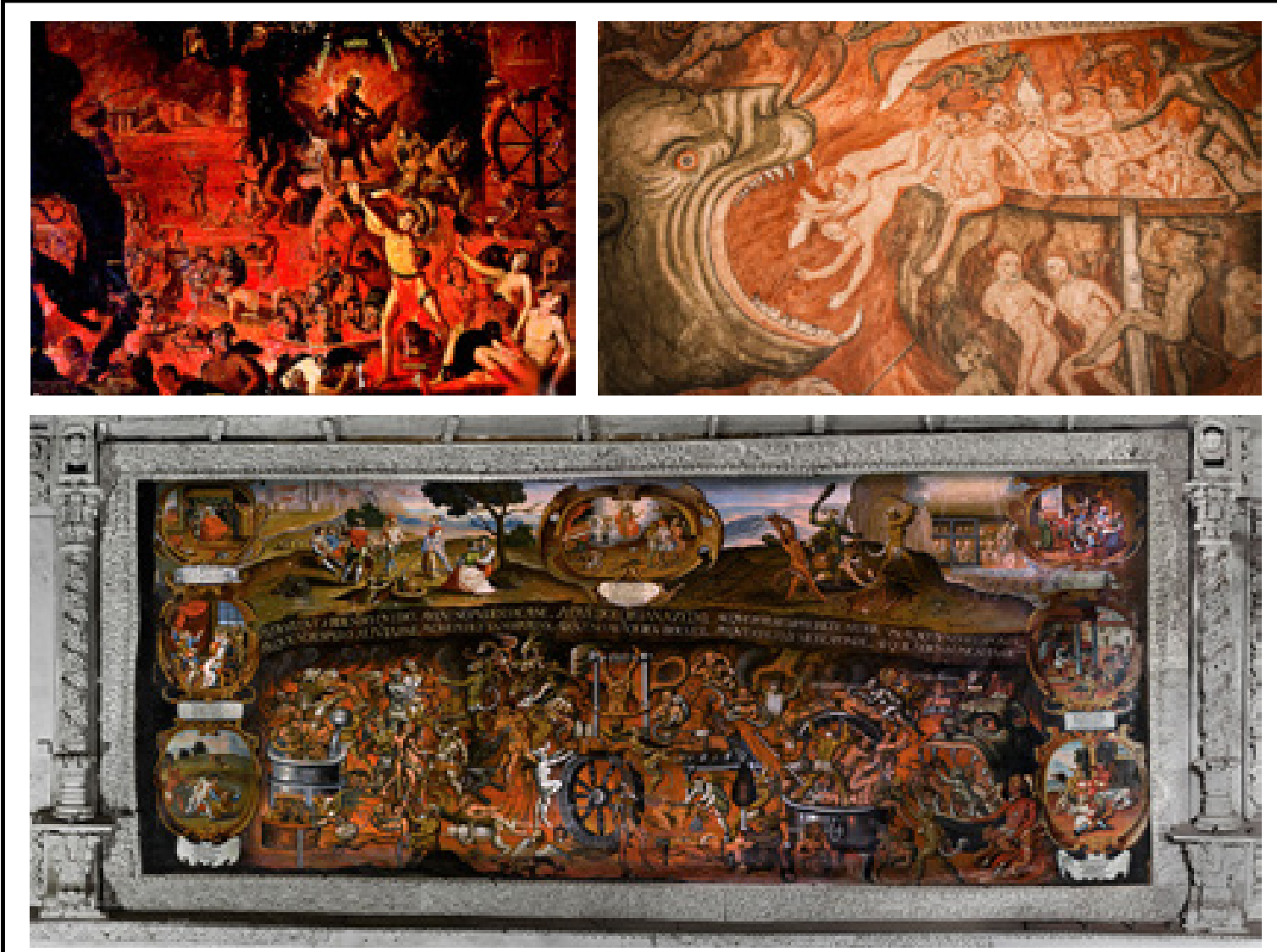

Figura 1. Fragmentos de murales sobre el Infierno en iglesias andinas: a) Compañía de Jesús, Quito; b) Huaro, Perú; c) Caquiaviri, Bolivia.

pinturas murales, que replicaban el estilo europeo, transmitieron los mensajes cristianos tanto a religiosos como a indígenas, en un doble juego didáctico de las imágenes (Báez Rubí, 2005). ${ }^{3}$

3 Esta comprensión común y compartida deriva del propio sistema religioso mesoamericano que poseía una sólida tradición de representación gráfica y escultórica, con una religiosidad que mantenía múltiples figuras de culto y un clero que se caracterizaba por su ascetismo. Por otra parte, los códices mexicanos con imágenes y figuras pintadas eran aspectos que entregaban puntos de contacto para el diálogo mutuo entre indígenas y españoles. En Nueva España, por ejemplo, los principios que organizaban los códices ilustrados de los aztecas fueron aprovechados por los religiosos que enseńaron a los pintores a desarrollar su arte hacia los modelos europeos (Flores, Kuon y Samanez, 1993, p. 11). Una visión de lo que sería un monasterio ideal se encuentra en la Rhetórica christiana publicada en 1579 por el monje mestizo Diego de Valadés. En ella se muestra
La Iglesia se valió de las artes como mecanismo de evangelización y adoctrinamiento, así como de la enseñanza de oficios europeos a la población nativa a modo de instrumento de occidentalización. De esta manera se comprende mejor la activa e importante participación de las órdenes religiosas en la organización de talleres artesanales y escuelas dirigidas por sus propios miembros al interior de los mismos conventos. Ahora bien, es importante tener en cuenta que este proceso es diferente en cada virreinato y lugar, pues dependerá de las distintas realidades, tanto de las poblaciones nativas como de las

cómo nativos y mendicantes se unían en un esfuerzo común de instrucción y conversión. La administración de los sacramentos y la introducción de los nativos a la doctrina de la Iglesia fueron dirigidas por monjes franciscanos que ocuparon imágenes para su enseñanza, mientras Pedro de Gante enseńaba a los nativos los oficios europeos. 
condiciones históricas y las disposiciones de las propias órdenes y sus diversos programas, entre otros factores. ${ }^{4}$ Estensoro (2003) establece la presencia de tres proyectos evangelizadores que en la práctica tuvieron importantes diferencias (el de los encomenderos, el del clero regular y el del clero secular). Sin embargo, dadas las restricciones lingüísticas y culturales del contacto, se optó por una evangelización mediada por los kuracas y principales para que estos, a su vez, difuminasen los contenidos catequéticos a sus familias y grupos, proceso en el que el programa evangelizador recepcionó y agenció una gran cantidad de relecturas nativas, como lo que veremos en las siguientes páginas.

Ya habiendo logrado cierta estabilidad en el período posconquista, el Concilio de Trento, hacia 1564, también abordó el problema del uso de las imágenes en el Nuevo Mundo, ${ }^{5}$ destacando tres arquetipos. El primero corresponde a "la imagen de culto que recoge el que se rinde a la imagen no por sí misma sino en virtud de la cosa representada (Dios, la Virgen, los Santos)", luego, en segundo lugar, "la imagen a la que no se tributa propiamente culto sino que sirve para la enseñanza e instrucción del pueblo cristiano, es decir, la imagen catequética y didáctica" y, finalmente, "la imagen que suscita poderosos sentimientos y afectos personales encamina-

4 Sabemos que desde su llegada en 1583, el pintor jesuita Bernardo Bitti, quien introduce el manierismo, realizó una serie de trabajos en los templos, como el retablo mayor de la iglesia jesuita, además de algunas obras como La coronación de la Virgen. Trabajó en Juli, Chuquisaca, Arequipa y otros lugares del virreinato, influyendo notoriamente en el arte de la región (Mesa y Gisbert, 1982).

5 "La iglesia oficial [...] no dejó de dictar, en los concilios provinciales y locales convocados a raíz del de Trento, normas sobre su uso en cuanto eficaz herramienta de instrucción y propaganda. En las reglas dirigidas a los pintores cristianos decía el cuarto Concilio Provincial mexicano: "no puede ni tiene arbitrio el artista para figurar según su capricho nuevos modos, nuevas revelaciones, nuevos paisajes que no estén apoyados o en la sagrada historia o en la profana y que solo se sostienen por la vana opinión del vulgo; porque no se puede permitir se le proponga al pueblo imagen ninguna de una cosa cuya lección se le prohíbe, y porque las pinturas son unos libros mudos que deben enseñar la verdad y no la mentira" (Rodríguez G. de Ceballos, 1999-2000, pp. 97-98. Los destacados son nuestros). dos a imitar la vida, acciones y actitudes de aquellos que las imágenes representan" (Rodríguez G. de Ceballos, 1999-2000, p. 89). Sin embargo, algunos años antes, en el primer Concilio Provincial de Nueva España, en 1555, ya se había abordado este mismo problema en el contexto de la evangelización de los naturales, pues la incitación a la devoción de imágenes católicas rápidamente fue utilizada por los indígenas en el culto a sus propias divinidades, para lo cual se recomendaba que "a fin de que la piadosa y loable costumbre de venerar las sagradas imágenes produzca el efecto para el que fueron instituidas, conserve el pueblo la memoria de los santos y los venere arreglando a su imitación la conducta de su vida y costumbres, es muy conveniente que no haya en las imágenes nada de profano e indecente que pueda impedir la devoción de los fieles" (Tejada 1855, vol. V, pp. 612-613, en Rodríguez G. de Ceballos, 1999-2000, p. 90).

Varias fueron las restricciones a los postulados generales de la iconografía evangelizadora que se aplicó a los naturales americanos. De esta manera, con el Concilio de Trento se reforzó la idea de que, por ejemplo, el culto al Santísimo Sacramento y "la doctrina del Purgatorio debía ser enseñada y predicada por doquier pero se debían excluir los sermones, predicados en lengua vulgar a la ruda plebe, las cuestiones muy difíciles y sutiles que nada conducen a la edificación, y con las que rara vez se aumenta la piedad" (sesión XXV, en López de Ayala (Trad.), 1847 [1564], pp. XLI-XLII). Indistintamente, esta discusión y normativa eclesiástica fue amplificada a nivel regional en los Concilios Limenses a lo largo del siglo XVI, subrayando que la pintura servía para que los indígenas se acercasen con respeto a los misterios de la fe (Castro, 2008; Vargas Ugarte, 1951). Este proceso de aprendizaje permitió la integración de numerosos indígenas, mestizos y criollos al sistema de producción artesanal y artístico europeo. ${ }^{6}$ Estas condiciones de producción son importantes

6 Lévano (2012) informa para el caso de Lima que en la segunda mitad del siglo XVI el pintor italiano Mateo Pérez de Alecio abrió un taller donde tenía como discípulos a criollos y mestizos. Entre sus obras destacan las pinturas de San Cristóbal, San Pedro y San Pablo en la Catedral, y los cuadros de Santo Domingo para el claustro del convento del Rosario de Lima, entre otras contribuciones. 
a tener en consideración, en la medida que permiten entender, aunque sea parcialmente, cómo se gestionaba cotidianamente el arte colonial tanto desde el punto de vista de la mano de obra como de las bases visuales que se utilizaron. ${ }^{7}$

Para el caso andino, Guaman Poma de Ayala en su Nueva Corónica incluye una mención acerca de los oficios artesanales coloniales. En primer lugar, a partir de la lámina 673 [687] señala: "PINTOR: LOS ARTIFICIOS, PINTOR, escultor, entallador, bordador, seruicio de Dios y de la Santa Yglecia”, englobando los oficios dentro de la esfera de la evangelización (Figura 2). En la foja siguiente el cronista andino señala que

[...] uiendo las santas hechuras, nos acordamos del seruicio de Dios. [...] Y ancí en las yglecias y tenplos de Dios ayga curiucidad y muchas pinturas de los santos. Y en cada yglecia ayga un juycio pintado. Allí muestre la uenida del señor al juycio, el cielo y el mundo y las penas del ynfierno, para que sea testigo del cristiano pecador. Y ancí se lo pague al dicho oficial la limosna de la fábrica o de la limosna que cayre o de los bienes de la yglecia. Y que le cirua y le dé de comer y no le ucope los caciques en sus borracherías (674 [688]. Los destacados son nuestros).

Del mismo modo, Antonio de la Vega (1600) relata que "ha avido notables mudanzas y conversiones de yndios con la consideración de juicio y gloria y penas de los condenados, que está todo Pintado por las paredes de esta yglesia y capilla y particularmente con las penas y castigos que en el infierno tienen los vicios y pecados de los yndios" (citado de Gisbert 2010, p. 17).

Precisamente, cuando De la Vega o Guaman Poma señalan que viendo las imágenes en los templos se acordarán los indígenas del servicio a Dios, no hacen otra cosa que explicitar precisamente uno de los principales objetivos que cumplió la pintura evange-

7 Uno de los aspectos que por espacio no podemos desarrollar en este artículo se refiere a la relación casi ineludible entre la pintura, la música, la danza y la castellanización.

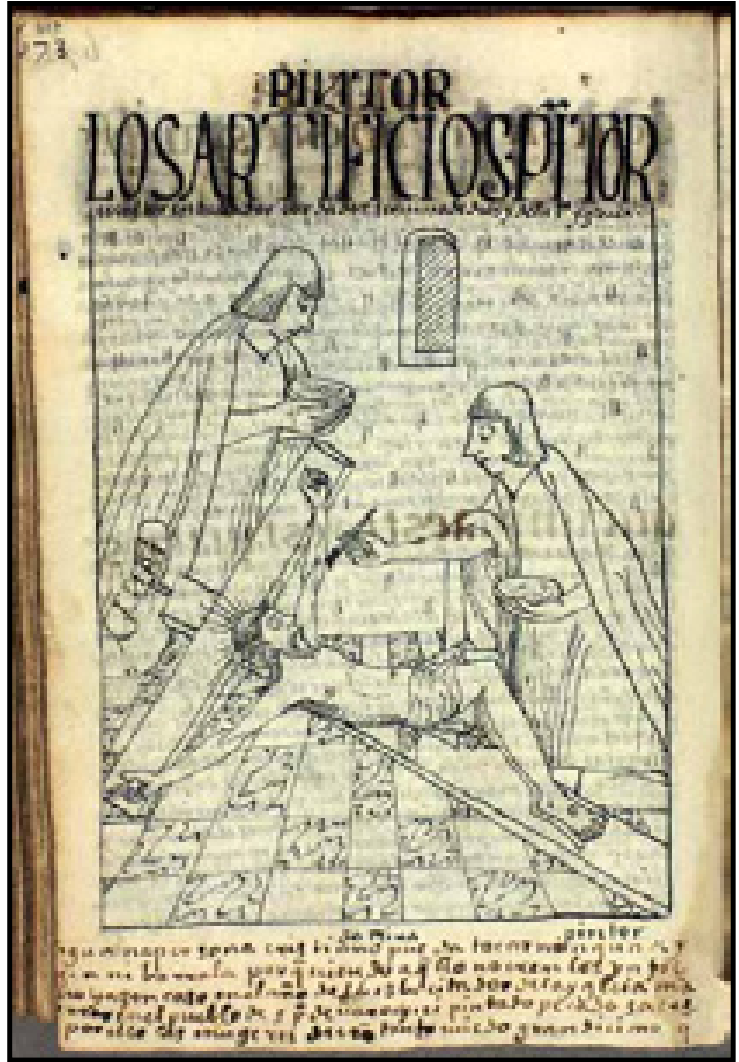

Figura 2. Guaman Poma, Lámina 673 [687] "Pintor: Los Artificios, Pintor, escultor, entallador, bordador, seruicio de Dios y de la Santa Yglecia”.

lizadora. Al respecto Flores, Kuon y Samanez explican que, puesto que la labor catequética no fue un camino llano para los misioneros,

[...]los doctrineros y evangelizadores debían conseguir que los nuevos cristianos conocieran lo esencial ${ }^{8}$ de la religión católica, como los misterios principales de la fe enunciados en el dogma, los mandamientos, los sacramentos que cada nuevo cristiano debía recibir y lo que se debía esperar y pedir a Dios, tal como se reza en el Padre Nuestro (Flores, Kuon y Samanez, 1993, p. 107).

8 Con respecto a los mecanismos narratológicos utilizados en los Andes coloniales que permitieron reducciones semióticas (tanto las de este tipo como otras), véase Martínez C. y Martínez S. (2013). 


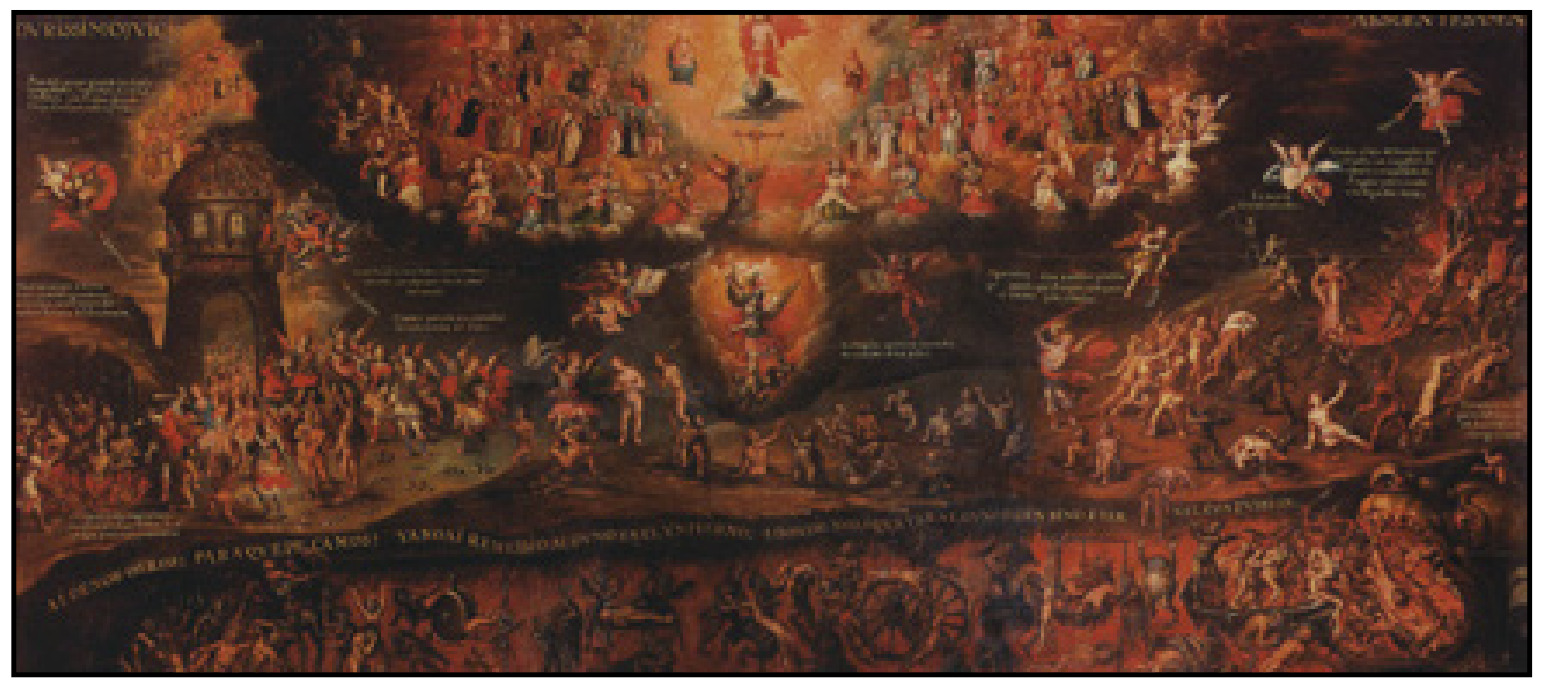

Figura 3. Juicio final. Iglesia de Carabuco, Bolivia.

En este contexto, la pintura evangelizadora (tanto de lienzos como de murales) conformó un complejo programa no solo visual, sino ideológico, narrativo y lingüístico, convirtiendo el espacio del adoctrinamiento en un mundo de pugnas ideológicas, culturales, cognitivas, textuales, etcétera. Ejemplos de ello son, entre otros, el mural de la iglesia de Andahuaylillas, el mismo dibujo de Guaman Poma y el mural de José López de los Ríos (Juicio final) que se encuentra en Carabuco, Bolivia, reproducido en la Figura $3 .{ }^{9}$

9 Foto de Carlos Rúa Landa (CNR, Bolivia), en Rodríguez Romero, A. y Gabriela Siracusano, G. (2011). La iconografía de Las Postrimerías: una propuesta de investigación interdisciplinaria. Papeles de Trabajo, 4(7), 114-128. Desgraciadamente no hemos podido conseguir una reproducción de este mural que nos permita leer los textos que se encuentran contenidos en cada circunferencia. Sobre la articulación del ars memorandi en los murales andinos, Rodríguez y Siracusano (2011, p. 117) señalan que: "Al examinar esta pintura, no sorprende que las visiones del infierno fueran consideradas en las artes de la memoria como las imagines agente por excelencia -imágenes que por su efectividad resultan indelebles-, mientras cada rincón del averno, reservado a las diferentes faltas a ser castigadas, fuera presentado como loci de la memoria" (Yates, 1974, pp. 117-119). Asimismo, las autoras, rastreando el origen iconográfico de estos murales, han sido capaces de proponer que la imagen que sirvió de base para estos murales es el Durissimum Iudicum, de Philippe Thomassin, aunque destacan que fue utilizado con gran ingenio, y fue producto de reformulaciones y selección por parte de los artistas andinos (op. cit., p. 123).
En varios murales andinos coloniales, encontramos una predominancia de los temas escatológicos que acompańaron el proceso evangelizador desde el principio de la Colonia. ${ }^{10}$ Esto se relaciona, además, con dos importantes hechos. Por una parte, al parecer las imágenes del paraíso, así como las bondades del discurso moralizante, no tuvieron la repercusión que se esperaba en la población andina, razón por la cual se privilegió la noción del infierno y del castigo como imágenes a desarrollar e inculcar en el imaginario de los indígenas, lo cual explica las réplicas de Leviatán, por ejemplo, en los murales de distintas iglesias a lo largo de la zona andina (ya no solo cusqueña). En segundo lugar, implica, desde el punto de vista lingüístico, la imposición de categorías (con sus definiciones asociadas) inexistentes prehispánicamente (tales como infierno, tierra y cielo en una relación tripartita y jerárquica) que forzaron su im-

$10 \quad \mathrm{Al}$ respecto, en el Primer Concilio Limense se advirtió que "los que son hijos de Dios y están señalados con su señal, que es el agua del baptismo, y guardan todo lo que él manda, cuando mueren, sus ánimas van al cielo con él, donde estarán para siempre en muy gran gloria [...] mientras los que viven en este mundo no son hijos de Dios, ni baptizan e no guardan sus mandamientos, cuando mueren, luego los demonios, que son nuestros enemigos, toman sus ánimas y las llevan al infierno que es la casa dellos, e donde hay muy grande obscuridad, e muy gran hedor, y muy grandísimo fuego, donde para siempre estarán quemando [...] sino que para siempre estén allí padeciendo por sus pecados" (Primer Concilio Limense, Constitución 38a , Vargas t. I, 1951, p. 29). 
plementación a través del refuerzo de los lexicones coloniales con la creación de términos como $u k h u$ pacha (infierno, lugar de los muertos), kay pacha (la tierra, el tiempo presente) y hanaq pacha (el cielo, la gloria). ${ }^{11}$ Llama la atención el fuerte desarrollo que tuvieron en la zona andina dos temas iconográficos: postrimerías y vidas de santos. Las postrimerías, o novísimos, despliegan el relato visual de la muerte, el juicio final, el infierno y la gloria (Rodríguez y Siracusano, 2011:114-115).

Ahora bien, ¿qué rol jugaron las cofradías en este panorama? Si bien los aspectos sociales y económicos de las cofradías coloniales ya han sido profusamente estudiados (Lévano, 2012; Díaz, Martínez y Ponce, 2014, entre otros), su papel en el proceso evangelizador y en el desarrollo artístico ha quedado relegado a un segundo plano. En el contexto colonial americano, las cofradías son herederas de las agrupaciones religiosas surgidas en el medioevo (Valenzuela, 2010; Benítez, 1998; Moreno, 1985), y cumplieron el rol de congregar a los miembros los cófrades- en torno a principios morales, reglas, cultos y redes sociales que garantizaban la supervivencia y reproducción de la organización gracias a la solidaridad, la asistencia mutua y la vigilancia moral de sus integrantes (Mancuso, 2007; Díaz, Martínez y Ponce, 2014). Lévano (2002, p. 79) indica que tres son los objetivos fundamentales de la cofradía: 1) promover el culto y celebración de la fiesta al santo patrono; 2) buscar la salvación del alma, a través de prácticas piadosas y espirituales y, 3) fomentar la caridad asistencial entre los miembros, preocupándose por la ayuda tanto a los enfermos, mujeres, nińos, pobres, presos, como a moribundos. ${ }^{12}$

11 Véase el himno "Hanaq pachap kusicuynin" del presbítero Juan Pérez Bocanegra. Una interesante reflexión acerca de la dificultad que tuvo la empresa evangelizadora para traducir conceptos cristianos se encuentra en Mannheim (2012), donde analiza la traducción que recibió, por ejemplo, la Virgen María como una de las pléyades en el Ritual Formulario de Pérez Bocanegra.

12 "Las cofradías pueden ser entendidas como entidades que propiciaban la asociatividad, estructurando un sistema económico que permitiera la autonomía de sus rentas y el cumplimiento de los objetivos sociales que demandaba, como era la caridad y la asistencia. La plataforma económica sobre la cual se sostenían las cofradías fue un régimen de cuotas entre los cófrades y socios, así como el pago de limosnas o la renta por
Las cofradías congregaron a espańoles, indios, mestizos y negros, facilitando así también el control social de indígenas y esclavos (Varón, 1982; De la Cruz, 1985; Garland, 1994; Díaz, Martínez y Ponce, 2014), así como también la enseñanza de los principios catequéticos que la Iglesia y el Estado requerían (Egoavil, 1986; Arias de Saavedra y López, 2000; Roselló, 2000; Bazarte y García, 2001). En tal escenario, operaron como mediadoras en un mundo colonial.

Una de las razones por las cuales las cofradías tuvieron un importante quehacer en el proceso evangelizador se debió a la escasez de clérigos y misioneros para evangelizar todo el virreinato, demanda que se vio en aumento, pues fueron los mismos indígenas los que buscaban satisfacer sus nuevas necesidades espirituales (Cohen, 2011). En este aspecto, la Iglesia notó rápidamente la necesidad de un mayor contingente que llevara la doctrina cristiana a todos los rincones. Sin embargo, por distintos motivos este llamado de auxilio no tuvo la respuesta esperada y prontamente las mismas poblaciones nativas fueron agenciándose distintos roles mediadores entre la empresa colonizadora y el mundo indígena, siendo las cofradías una de las instancias más eficientes para dichos efectos (Díaz, Martínez y Ponce, 2014), tal como quedaría consignado en las Constituciones de las cofradías de naturales, donde se indica que todos los cófrades deben saber

[...] la doctrina xtiana y la enseñen en sus casas, a su familia, y si al punto fuese toma des cuidado que despues de entrado se le oluidase sea echado de la hermandad sienbre que no la supiere”. Aún más, los cófrades también debían enseñar la "doctrina xtiana, a todos los Yos [indios] espeçialmente a los biejos y viejas Procuren encaminarlos a dios y ayudarles a saluar, sus animas en Especial aPartar Los ydolatrias y hechizerias mos-

inmuebles o posesiones (chacras, parcelas, casas) pertenecientes a la institución (Palomo, 2000; Lévano, 2002; Moreno, 1985). En otro plano, funcionaron como entidades vinculadas a las actividades mineras, permitiendo poseer un llamativo patrimonio y ajuares de tesoros para altares y templos que solo las cofradías mineras podían cubrir (Mancuso, 2007; Hausberger, 1997)” (Díaz, Martínez y Ponce, 2014, p. 102). 
trándoles su gran ceguedad [sic], y perdiçion (ADHC, Colegio de Ciencias, Legajo no 11, 1600-1675, cuad. 18, f. 2v).

\section{Las cofradías de naturales y las pin- turas de los templos}

Las cofradías que se constituyeron en el territorio andino jugaron un rol de vital importancia en el programa evangelizador, al buscar la inserción de la república de indios en la vida de buenas costumbres, orden y civilidad que el coloniaje requería con tanto ahínco. En gran medida las cofradías, ya instaladas en el seno de la vida colonial, permitieron a la población nativa, así como también a los afrodescendientes, una activa participación en los nuevos escenarios sociales y de culto catequético, promoviendo nuevas formas de asociación y de participación, ejemplo de lo cual es la conocida serie de cuadros del Corpus Christi que se encuentra custodiada actualmente en el Museo del Palacio Arzobispal del Cusco, donde aparecen representadas algunas cofradías incas de finales del siglo XVII, tal como se puede ver en la Figura 4.

La participación de las élites incaicas en las cofradías, así como de la población andina en general, quedó atestiguada ya desde los albores de la Colonia, dando cuenta asimismo de la amalgama ritual que permitieron en las performatividades del calendario católico: ${ }^{13}$

[En la ciudad de los Reyes] El Padre Bracamonte tiene cuidado de la doctrina de los niños de las esqüelas y de los indios, los quales son tantos los que se juntan que con ser la iglesia razonable de grande, apenas caben las mugeres solas, porque los honbres están en

13 Bajo el virreinato toledano se organizó el territorio en 119 reducciones, a las cuales se sumaron 19 más hacia la primera década del siglo XVII, aunque el espacio geográfico para ese entonces había cambiado en virtud de la desanexión de los nuevos obispados de La Paz, Huamanga y Arequipa.

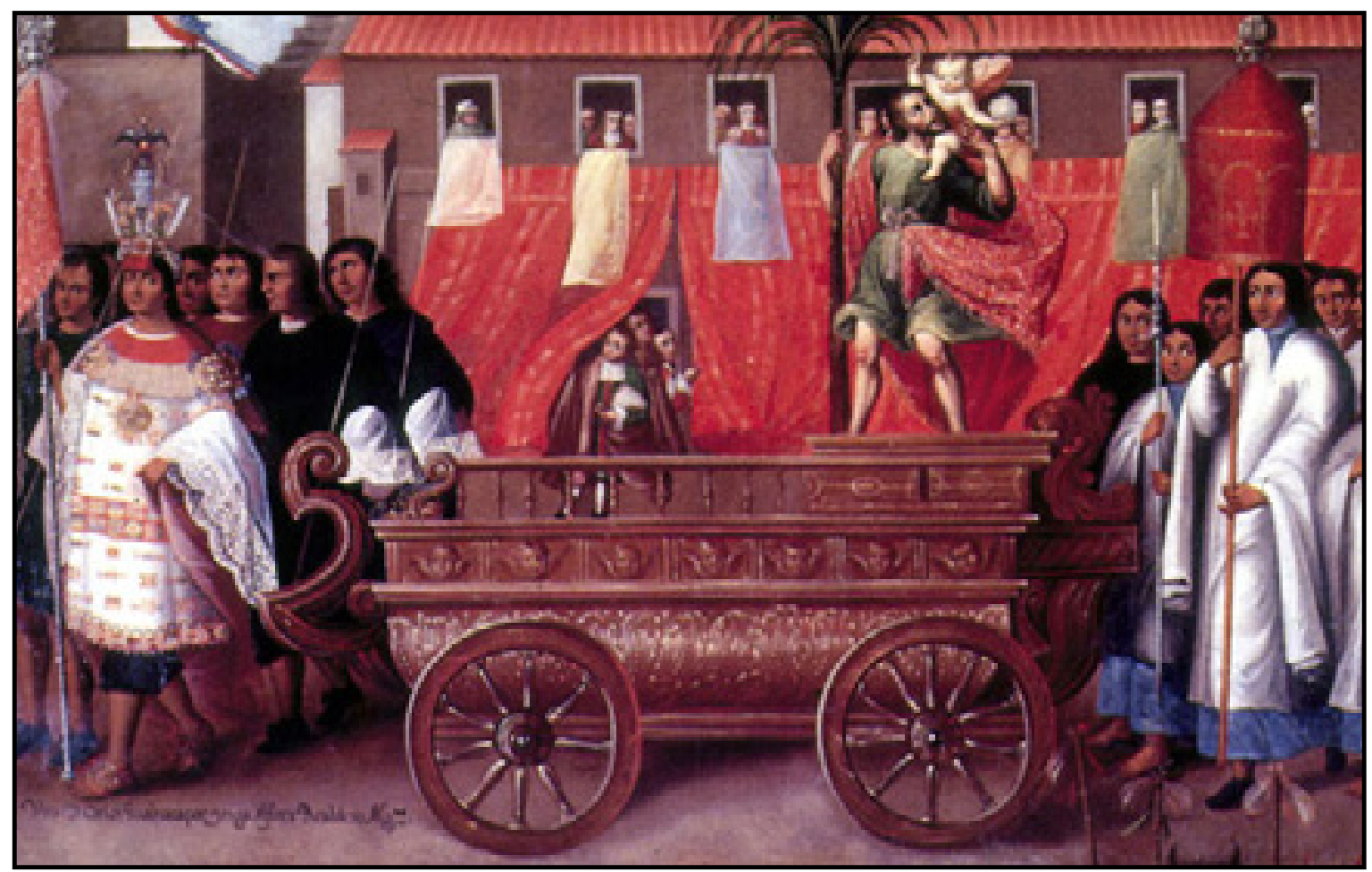

Figura 4. Cuadro perteneciente a la serie del Corpus Christi (Museo del Palacio Arzobispal del Cusco). 
el patio de la casa que lo ocupan casi todo, y el púlpito está de tal manera que todos oyen al que predica; $y$ an hecho una cofradía entre sí para obligarse más a venir a ser enseñados. Tienen en nuestra casa una cruz que an hecho muy rica para salir con ella a la doctrina; y ai sus alguaziles dellos mesmos para regirlos y allegarlos, y júntanse más de dos o tres mill dellos entre indios e indias, que es cosa de grande alabança de Dios vellos ir en proseción por las calles desta ciudad todos los domingos, y van media dozena de Hermanos de casa, de trecho a trecho, diziendo la doctrina, y ellos respondiendo, y los niños de los indios van delante con la cruz, que pone gran devoción, y bolvemos con ellos a nuestra iglesia donde se les hacen las preguntas en nuestra lengua y en la suya, porque las tenemos ya traduzidas, y un Hermano que se dize Piçarro, que sabe bien le lengua, hijo de un conquistador de los principales destos Reinos, les haze sienpre alguna plática que lleva estudiada en su lengua, y quatro indezicos que tenemos en casa, los quales a vestido el Padre Provincial de limosnas que para ellos le dieron, a su modo muy ricamente, van allí, los quales van instruídos en las preguntas, ponen grande admiración a los indios y afición que nos inportunan los caciques con sus hijos y otros mochachos, y gustan tanto deste modo, que ellos vienen entre semana a que los enseñemos y demos por scrito las respuestas de la doctrina y que les demos cantarcicos devotos, y van por las calles, que muchos los topan, preguntándose unos a otros la doctrina, cosa que hasta agora pocas vezes se veía, y entre ellos tratan diciendo: Si estos Padres obieran venido antes, obiéramos conocido mejor a Dios, y fuéramos mejores christianos. Da tanto contento esto a todos los españoles, ver junto tantos indios y con tanta affición, y cantando por las calles la doctrina que, abobados, se paran por ellas y por las ventanas, y se van tras nosotros. Traen los indios e indias sus chiquitos y el Padre [2v] Bracamonte dales siempre regalillos que los estiman en tanto, que sea
Dios glorificado por todo. Hase quitado por entretenerlos desta manera las fiestas que antes tenían, sus bailes y borracheras, de lo qual se seguían grandes idolatrías y offensas de Dios y muertes. Con esto se les a evitado, y quando la procesión de indios se enqüentra con la de los negros que suelen, salúdanse con: Alabado sea Jesucristo, los unos a los otros, que cierto las piedras se movieran a devoción, y quando vemos que sin buscarlos se nos vienen tanto número para que salgamos a las doctrina, y que en España hera menester para cada uno su alguazil de los que se avían de juntar, no podemos dexar de desear que vengan muchos Padres y Hermanos para que se enpleen en tantas almas como en estos Reinos, así españoles como de indios, como de morenos, están clamando por uno de la Conpañia que los doctrine (Documento 57, Pater didacus Bracamonte Patribus ac fratribus societatis iesu, Lima 21 Ianuarii 1569, pp. 258-260).

Esta carta entrega valiosísima información acerca de las actividades que las cofradías llevaban a cabo, dando cuenta de cómo expandieron sus espacios de acción no solo en las procesiones, fiestas y actividades comunitarias, sino también en el espacio arquitectónico tal como se lo concebía en la época colonial, es decir, como una más de las instancias de colonización de los imaginarios, constituyéndose los edificios mismos en un espacio textualizado por las pugnas ideológicas y culturales. Las iglesias coloniales de toda América rebosaban de pinturas, lienzos e imágenes de bulto reforzando visual y kinésicamente el culto cristiano que se transmitía en la eucaristía $\mathrm{y}$ en las horas de doctrina.

A partir de la revisión de fuentes documentales de los siglos XVI y XVII, es posible efectuar una reconstrucción del panorama de las cofradías en el Obispado cusqueño. Si bien la mayor parte de los datos provienen de las visitas ordenadas por Mollinedo y Angulo, ${ }^{14}$ hacia las últimas décadas del siglo XVII

14 El obispo Manuel Mollinedo y Angulo estuvo a cargo de la administración espiritual del obispado desde 1673 y por un espacio de 25 años, durante los cuales incentivó intensamente el culto religioso no solo entre la pobla- 


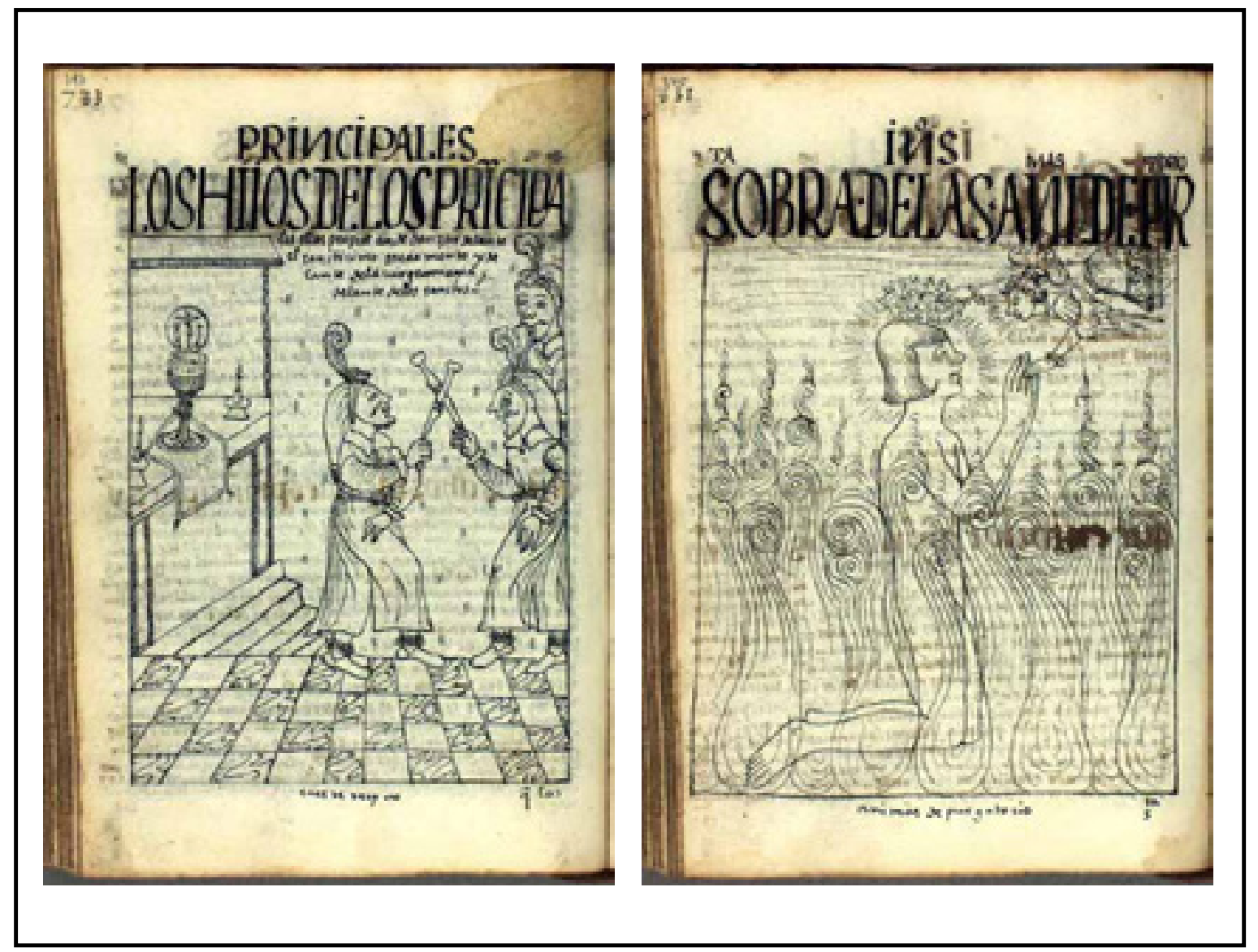

Figura 5. Láminas 783 [797] y 831 [845] representando a los cófrades del Santísimo Sacramento y de las Ánimas del Purgatorio, respectivamente.

ción europea sino también entre la criolla, incluyendo a las élites indígenas y a los indígenas del común. Parte de su colosal obra queda reflejada en las informaciones que se presentan en la tabla a continuación, donde se puede ver claramente el auge en la conformación de cofradías. Esta tabla se confeccionó a partir de las informaciones obtenidas en las visitas ordenadas por el obispo Mollinedo y Angulo y con los informes que los párrocos entregaron al mismo obispo (en Guibovich y Wuffarden, 2008; y de Villanueva Urteaga, 1982, respectivamente). Entre paréntesis [ ] se encuentra la información de las cofradías que se mandó fundar luego de la visita. A pie de página se encuentra la información de aquellos lugares en los que no se dejó consignada la cantidad de cofradías o de feligreses. Una versión completa de esta tabla se encuentra en Martínez 2014, donde se puede apreciar además la consignación de iglesias a construir, las escuelas asociadas a las mismas, los párrocos a cargo de su administración y las órdenes religiosas por sector. algunas informaciones contenidas en la documentación archivística nos permiten ahondar este panorama entendiendo, algunas de las actividades de dichas cofradías en cuanto a su actividad artística y doctrinal. Si revisamos con atención la siguiente tabla 1, podremos comprender la importancia que tuvo, hacia finales del siglo XVII, la constitución de cofradías como parte del programa evangelizador. Pero prestando un poco más de atención aún, veremos que casi todos los pueblos o anexos tienen, o deberán tener, dos cofradías que fueron fundamentales: del Santísimo Sacramento y de las Ánimas del Purgatorio, que además son las únicas representadas visualmente por Guaman Poma en su obra (Figura 5). 
Tabla 1. Cofradías de indios y de españoles en el Cusco del siglo XVII ${ }^{15}$

\begin{tabular}{|c|c|c|}
\hline \multicolumn{3}{|c|}{$1674^{16}$} \\
\hline Lugar & Cofradías & $\mathrm{N}^{\circ}$ feligreses \\
\hline Sicuani & $\begin{array}{l}\text { 8: Concepción de Nuestra Señora, Niño Jesús, Santísimo sacramento, Nuestra Señora de las } \\
\text { Cabezas, Santísimo Sacramento, de San Martín, del Santo Nombre de Jesús, Nuestra Señora de la } \\
\text { Purificación }\end{array}$ & 2000 \\
\hline Ayaviri & 2: Santo Christo, Nuestra Señora de la Purificación & 1500 \\
\hline Pucará & $\begin{array}{l}\text { 4: Santísimo Sacramento, Nińo Jesús, Nuestra Seńora de la Limpia Concepción Ánimas de } \\
\text { Purgatorio }\end{array}$ & 1000 \\
\hline Lampa & 3: Concepción de Nuestra Señora, Santísimo Sacramento, Ánimas del Purgatorio & 2500 \\
\hline Cavanilla & 2: Santísimo Sacramento y Ánimas de Purgatorio & 600 \\
\hline Mańaso & 2: Santísimo Sacramento, Ánimas del Purgatorio & 1000 \\
\hline Juliaca & 2: Santísimo Sacramento, Ánimas de Purgatorio & 1500 \\
\hline Taraco & $\begin{array}{l}\text { 7: Ánimas de Purgatorio, Nuestra Señora de la Asunción, Nuestra Señora del Carmen, del Dulce } \\
\text { Nombre de Jesús, del Espíritu Sancto, Nuestra Señora de Copacabana, Santísimo Sacramento }\end{array}$ & \\
\hline Samán & 3: Santísimo Sacramento, Concepción de Nuestra Señora, Ánimas del Purgatorio & 500 \\
\hline Caminaca & 2: Santísimo Sacramento, Ánimas de Purgatorio & 2000 \\
\hline Arapa & 1: Santísimo Sacramento & 500 \\
\hline Chupa & 2: Santísimo Sacramento, Ánimas de Purgatorio & 1500 \\
\hline Azángaro & $\begin{array}{l}\text { 7: Ánimas de Purgatorio, Santísimo Sacramento, Nuestra Señora del Rosario, Niño de Jesús, } \\
\text { Nuestra Señora de Assumpción, Nuestra Señora de la Purificación, Limpia Concepción de Nuestra } \\
\text { Seńora }\end{array}$ & 1500 \\
\hline Assillo & 3: Nuestra Señora del Rosario, San Sebastián, Santo Cristo & 2000 \\
\hline Horurillo & $\begin{array}{l}\text { 6: Concepción de Nuestra Señora, de la Purificación, Niño Jesús, Ánimas de Purgatorio, de la } \\
\text { Santa Cruz. }\end{array}$ & 2000 \\
\hline Nuñoa & 3: Concepción de Nuestra Señora, Nombre de Jesús, San Pedro & \\
\hline Chungara & $\begin{array}{l}\text { 7: San Francisco, de la Concepción de Nuestra Señora, Niño Jesús, Señora Santa Ana, Niño de } \\
\text { Jesús, Nuestra Señora de las Nieves }\end{array}$ & 1074 \\
\hline Macarí & $\begin{array}{l}\text { 6: Santa Lucía, Niño de Jesús, Nuestra Señora del Rosario, San Juan, Santa Bárbara, de la } \\
\text { Purificación }\end{array}$ & 1000 \\
\hline Cacha & $\begin{array}{l}\text { 10: Santísimo Sacramento, Niño Jesús, San Pedro, Concepción de Nuestra Señora, de la } \\
\text { Purificación }\end{array}$ & 2500 \\
\hline Quiquixana & $\begin{array}{l}\text { 7: San Pedro, Nuestra Señora de Copacabana, Concepción de Nuestro Señora, del Niño Jesús, } \\
\text { Santísimo Sacramento, San Bartholomé, Ánimas de Purgatorio }\end{array}$ & 1000 \\
\hline $\begin{array}{l}\text { Andaguaililla la } \\
\text { Chilca }\end{array}$ & 6: Santísimo Sacramento, San Pedro, Nuestra Seńora de Monserrate & 1000 \\
\hline Oropessa & 9: Virgen de la Ermita & 1500 \\
\hline \multicolumn{3}{|c|}{1675} \\
\hline Tinta & $\begin{array}{l}\text { 12: San Bartholomé, Nuestra Señora de la Soledad, Ánimas de Purgatorio, Santísimo Sacramento, } \\
\text { Nuestra Señora de Copacabana, Nombre de Jesús, de San Antonio, Niño de Jesus, Natavidad de } \\
\text { Nuestra Señora, Santísimo Sacramento San Pedro, Ánimas del Purgatorio }\end{array}$ & 3500 \\
\hline
\end{tabular}

15 Esta tabla se confeccionó a partir de los datos de las visitas ordenadas por el obispo Mollinedo entre 1674-1687 (Guibovich, P., Wuffarden, L. E., 2008) y de los informes entregados por los mismos párrocos al obispo Mollinedo en 1689 (Villanueva Urteaga, H., 1982).

16 Santiago de Pupuxa (2/500), Hatuncollas (¿?/200), Cavana (¿?/800), Checacupe (4/1500), Urcos (5/1800), San Gerónimo (7/500). 


\begin{tabular}{|c|c|c|}
\hline Langui & $\begin{array}{l}\text { 5: Niños de Jesús, Nuestra Señora de la Asunción, Purificación de Nuestra Señora, Purificación de } \\
\text { Nuestra Señora, Niños Jesús }\end{array}$ & 2000 \\
\hline Checa & $\begin{array}{l}\text { 6: Santísimo Sacramento, de la Visitación de Nuestra Señora, San Andrés, de la Concepción de } \\
\text { Nuestra Señora, de las Ánimas de Purgatorio, del Niño Jesús, [Ánimas del Purgatorio] }\end{array}$ & 2000 \\
\hline Pichugua & $\begin{array}{l}\text { 6: Santísimo Sacramento, Limpia Concepción de Nuestra Seńora, Nombre de Jesús, Santa Lucía, } \\
\text { Nuestra Seńora de la Candelaria, San Pedro }\end{array}$ & 2500 \\
\hline Yauri & $\begin{array}{l}\text { 7: Niño de Jesús, Limpia Concepción de Nuestra Señora, Purificación de Nuestra Señora, del } \\
\text { Santísimo Sacramento, San Joseph, Santa Ana, Ánimas de Purgatorio }\end{array}$ & 2200 \\
\hline Coporaque & $\begin{array}{l}\text { 5: Santísimo Sacramento, Limpia Concepción de Nuestra Señora, Nombre de Jesús, San Juan } \\
\text { Baptista, Santo Cristo. }\end{array}$ & 2500 \\
\hline Belille & 5: Santísimo Sacramento, de la Concepción & 1500 \\
\hline Santo Thomas & 8 & 2600 \\
\hline $\begin{array}{l}\text { Llusco y } \\
\text { Quinota }\end{array}$ & $\begin{array}{l}\text { 5: Purificación de Nuestra Seńora, San Juan, Santiago, Santísimo Sacramento, de la Asunción de } \\
\text { Nuestra Seńora [+ } 2 \text { Ánimas del Purgatorio] }\end{array}$ & 3000 \\
\hline Colquemarca & 2: Santísimo Sacramento, Concepción de Nuestra Señora [+Ánimas del Purgatorio] & 3000 \\
\hline Capacmarca & 4: Asunción de Nuestra Señora, Santísimo Sacramento, Ánimas de Purgatorio, Santiago & 1000 \\
\hline Yanaoca & 4: Santísimo sacramento, Nombre de Jesús, de la Concepción de Nuestra Seńora, de Santiago & 2000 \\
\hline Pampamarca & 10 & 3300 \\
\hline Pomacanche & $\begin{array}{l}\text { 6: Niño de Jesús, Santísimo Sacramento, Niño de Jesus, Santa Lucía, San Juan Concepción de } \\
\text { Nuestra Señora }\end{array}$ & 3500 \\
\hline Acomaio17 & $\begin{array}{l}\text { 9: (4 de Acomayo y } 5 \text { de Acos): Santísimo Sacramento, Niño de Jesús, San Pedro, Santísimo } \\
\text { Sacramento, Ánimas de Purgatorio, Nuestra Señora de Monserrate, Niño de Jesús, Nuestra Señora } \\
\text { de Copacabana }\end{array}$ & 4500 \\
\hline Papres $^{18}$ & $\begin{array}{l}\text { 6: ( } 2 \text { de Papres, } 1 \text { de Pirqui, } 2 \text { Corma, } 1 \text { Sanca) Misericordia, Niño Jesús, Santísimo Sacramento, } \\
\text { Santísimo Sacramento, Santiago Domingo }\end{array}$ & \\
\hline Sangarará & $\begin{array}{l}\text { 15: (5 Sangarará, } 2 \text { Yanampampa, } 5 \text { Acopia, } 3 \text { Marcaconga) Santísimo Sacramento, Nuestra } \\
\text { Seńora de la Candelaria, Nińo Jesús, Nuestra Señora de la Nieves, Concepción de Nuestra señora, } \\
\text { Santísimo Sacramento, Santísimo Sacramento, Nombre Jesús, Nuestra Señora de Copacabana, San } \\
\text { Gerónimo, San Antonio, Santa Catalina, Niños Jesus, San Juan Baptista }\end{array}$ & 3500 \\
\hline \multicolumn{3}{|c|}{$1676^{19}$} \\
\hline Cayacai & $\begin{array}{l}\text { 6: (3 Cayacai, } 3 \text { Guadac) Nuestra Señora de la Purificación, Niño Jesús, Santiago [+Santísimo } \\
\text { Sacramento, Ánimas del Purgatorio] }\end{array}$ & \\
\hline Catca & $\begin{array}{l}\text { 11: Santísimo Sacramento, de Nuestra Señora de la Candelaria, del Rosario, del Niño Jesús, San } \\
\text { Francisco, San Bartholomé, Nuestra Señora del Rosario, de la Purificación, San Pablo [+Ánimas } \\
\text { del Purgatorio] }\end{array}$ & \\
\hline
\end{tabular}

17 Acos: "Ay tres cofradías corrientes: el Ssmo. N.Sa. del Rosario, y las Animas pagan siete pesos por misa, vísperas, y prosecion, y lo mismo pro los finados esto mismo es en Acomayo, con diferencia q’ la Iglesi no tiene más q’ tres fanegas de maíz.- Ay otra cofradía o hermandad de los Españoles N.S. de Belen, entrando al Pueblo de Acomayo" (Villanueva Urteaga, 1982, p. 142).

18 Papres: "Tiene dos cofradías una de N.P.S. Domingo y de N. Sra. del rosario y pagan en sus festividades a siete pesos por misa prosesion y vísperas" (Villanueva Urteaga, 1982, p. 152) y del pueblo de corma: "Tiene tres Cofradías una del Patron Santiago. Otra del Seńor. Otra de Nra. Señora con la advocación del rosario pagan siete pesoso en la festividades de misa prosecion y vísperas" (Villanueva Urteaga, 1982, p. 155).

19 En esta visita varios pueblos, curatos y anexos aparecen con escasa información relativa solo al número de cofradías y de feligreses: Garacondo (7 /2000), Zurite (6/3000), Limatambo (10/4000), Chinchaipuquio (10/2000), Anta (20/5500), Circa (8/ 1000), Ancobamba (3/ 800), Colcabamba (8/1200), Soraya (12/ 1500), Pacsica (3), Yanaca (3/150), Chuquinga (4/1000), Chaluanca (4/600) Pampamarca (7/800), Sabaino (3/200), San Pedro de Haquira (3/ 1200), Calca (10/3000), Yucay (12/1500), Gauyllabamba y Urquillos (6/2000), Urubamba (11/4000), Ollantaytambo (8/2500), Mara (12/3500), Lamay /7/1500), Palcaro (3/150). 


\begin{tabular}{|c|c|c|}
\hline Paucartambo & 10 & 5000 \\
\hline Píscac & 7: (3 San Salvador, 4 Taray) Santísimo Sacramento, de la Asunción de Nuestra Seńora, San Pedro & 2000 \\
\hline Pantipata & 7 [+2 Ánimas del purgatorio] & 2000 \\
\hline Curahuasi & $\begin{array}{l}\text { 5: Santísimo Sacramento, Nuestra Señora de la Candelaria, Puríssima Concepción, San Nicolás y } \\
\text { San Juan }\end{array}$ & 2000 \\
\hline Guanipaca & 2: Santísimo Sacramento, Nuestra Seńora de la Purificación & \\
\hline Abancay & $\begin{array}{l}\text { 4: Nuestra Señora del Rosario, las de las Ánimas, Santo Cristo, san Francisco [+ Santísimo } \\
\text { Sacramento] }\end{array}$ & 3500 \\
\hline Lambrana & 3: (2, Lambrana, 1 Caypi) Santísimo Sacramento, Asunción de Nuestra Seńora & 1500 \\
\hline Mollebamaba & 3 [+ Santísimo Sacramento, Madre de Dios y Ánimas del Purgatorio] & 300 \\
\hline Antabamba & 2 [+Ánimas del Purgatorio] & 1000 \\
\hline Guaquirca & 2 [+Ánimas del Purgatorio] & 1200 \\
\hline Pachaconas & 1 [+Ánimas del Purgatorio] & 300 \\
\hline Turpay & 2 [+Santísimo Sacramento, Ánimas del Purgatorio] & 600 \\
\hline Oropesa & 2 [+ Santísimo Sacramento, Ánimas del Purgatorio, 2 de los patrones] & 500 \\
\hline Ayrihuanca & 1 [+Santísimo Sacramento, Ánimas del Purgatorio] & 300 \\
\hline Haquira & 0 [+Santísimo Sacramento, Ánimas del Purgatorio] & 300 \\
\hline Mara & 4 [+Santísimo Sacramento, Ánimas del Purgatorio] & 600 \\
\hline Pitic & 2 [+Santísimo Sacramento, Ánimas del Purgatorio] & 150 \\
\hline Tambobamba & 5 [+Santísimo Sacramento, Ánimas del Purgatorio] & 1100 \\
\hline Cullurqui & 0 [+Santísimo Sacramento, Ánimas del Purgatorio] & 100 \\
\hline San Agustín & 2 [+Santísimo Sacramento, Ánimas del Purgatorio] & 100 \\
\hline Guayllate & 6 [+Santísimo Sacramento, Ánimas del Purgatorio] & 1300 \\
\hline Chuquibamba & 4 [+Santísimo Sacramento, Ánimas del Purgatorio, Nuestra Señora, del patrón] & 200 \\
\hline $\begin{array}{l}\text { Colpa y } \\
\text { Pitoguanca }\end{array}$ & 2 [+Santísimo Sacramento, Ánimas del Purgatorio] & 800 \\
\hline \multicolumn{3}{|c|}{$1687^{20}$} \\
\hline San Sebastián & \multicolumn{2}{|c|}{$\begin{array}{l}\text { 13: Santísismo Sacramento, Nińo Jesús, San Pedro, La de Veracruz, San Sebastián, San Juan Evangelista, Nuestra } \\
\text { Señora del Rosario, Sanctísima Trinidad, La de la Misericordia, San Juan Baptista, San Miguel Arcángel, La de la } \\
\text { Asunción }\end{array}$} \\
\hline San Gerónimo & \multicolumn{2}{|c|}{$\begin{array}{l}\text { 9: Purísima Concepción de Nuestra Señora, La de la Vera Cruz, Niño Jesús, Nuestro Padre San Pedro, San } \\
\text { Juan Baptista, Apóstol Santiago, Apostol San Bartholomé, de San Gerónimo, Angélico Doctor Santo Thomas } \\
\text { [+Santísimo Sacramento, Ánimas del Purgatorio] }\end{array}$} \\
\hline San Gerónimo & \multicolumn{2}{|c|}{$\begin{array}{l}\text { 9: Purísima Concepción de Nuestra Señora, de la Vera Cruz, Niño Jesús, Nuestro Padre San Pedro, San Juan } \\
\text { Bautista, Apostol Santiago, Apostol San Bartholomé, La de San Gerónimo, Angélico doctor Santo Thomas } \\
\text { [+Santísimo Sacramento, Ánimas del Purgatorio] }\end{array}$} \\
\hline Urcos & \multicolumn{2}{|c|}{$\begin{array}{l}10 \text { (6 Urcos, } 4 \text { Guaroc): Sanctísimo Sacramento, Niño de Jesus, Purísima Concepción de Nuestra Señora, Apóstol } \\
\text { Santiago, San Cristobal, Cofradía del Señor, Santísimo Sacramento, del Niño Jesús, Purísima Concepción, San } \\
\text { Juan Bautista }\end{array}$} \\
\hline Andaguaylillas & \multicolumn{2}{|c|}{$\begin{array}{l}\text { 7: Santísimo Sacramento, Veracruz, Dulce Nombre de Jesús, Misericordia, Nuestra Señora de Monserrate, Nuestra } \\
\text { Señora del Rosario, Nuestro Padre San Pedro }\end{array}$} \\
\hline Oropesa & \multicolumn{2}{|c|}{$\begin{array}{l}\text { 12: Santísimo Sacramento, San Salvador, Niños Jesús, Concepción, Nuestra Señora de la Consolación, Nuestra } \\
\text { Señora de la Purificación, Nuestra Señora de Monserrate, Nuestro Padre San Pedro, Ánimas de Purgatorio, } \\
\text { Asunción de Nuestra Seńora, Jesús Nasareno }\end{array}$} \\
\hline Caycay & \multicolumn{2}{|c|}{$\begin{array}{l}\text { 7: (3 Caycay, } 4 \text { Guasac) Dulce nombre de Jesús, Purificación de Nuestra señora, Niño de Jesús, Nuestra Señora de } \\
\text { Belén, Nuestro Padre San Pedro, San Francisco. }\end{array}$} \\
\hline Marcapata & \multicolumn{2}{|c|}{ 5: Santísimo Sacramento, Concepción de Nuestra Señora, Benditas Ánimas, Niño de Jesús } \\
\hline
\end{tabular}

20 En esta visita no hay información de los feligreses. 


\begin{tabular}{|c|c|}
\hline Písac & $\begin{array}{l}\text { 10: (2 Pisac, } 4 \text { San Salvador, } 4 \text { taray). Santísimo Sacramento, Asunción de Nuestra Señora, de San Salvador, } \\
\text { Purísima Concepción, San Joan Baptista, Sanctisimo sacramento, de la Purificación de Nuestra Señora, Santa } \\
\text { María Magdalena }\end{array}$ \\
\hline Paucartambo & $\begin{array}{l}\text { 18: ( } 5 \text { Paucartambo, } 4 \text { Llaullipata, } 4 \text { Colquepata } 1 \text { Ayre, } 1 \text { Mollomarca, } 3 \text { cofradías de indios en Paucartambo) } \\
\text { Santísimo Sacramento, Santo Cristo de la Coluna, Nuestra Seńora del Rosario, Soledad, Ánimas del Purgatorio, } \\
\text { Purísima Concepción, Nuestro Padre San Pedro, Apóstol Santiago, Asunción de Nuestra Señora, Purificación de } \\
\text { Nuestra Señora, Apóstol Santiago, San Juan Bautista, Nuestro Padre San Pedro, Nilo de Jesús, Nuestra Señora del } \\
\text { Rosario, Evangelista San Marcos }\end{array}$ \\
\hline Catca & $\begin{array}{l}\text { 9: (5 Cacta, } 1 \text { Chicchina y Camara, } 2 \text { Ocongate, } 1 \text { Lauramarca y Capana). Santísimo Sacramento, Dulce Nombre } \\
\text { de Jesús, Nuestra Seńora del Rosario, San Juan Baptista, Santa Bárbara, Nuestra Señora de la Candelaria, San Pablo }\end{array}$ \\
\hline Lamay & $\begin{array}{l}6 \text { (3 Lamay, } 3 \text { Coya): Dulce Nombre de Jesús, Purificación de Nuestra Seńora, Apóstol Santiago, Niño Jesús, } \\
\text { Purísima Concepción, Nuestra Señora, San Esteban }\end{array}$ \\
\hline Calca & $\begin{array}{l}\text { 10: Niño Jesús, Resurección del Señor, Asunción de Nuestra Señora, Asunción de Nuestra Señora, Purísima } \\
\text { Concepción de Nuestra Señora, Purificación de Nuestra Señora, San Juan Bautista, Nuestro Padre San Pedro, San } \\
\text { Pablo, San Sebastián, }\end{array}$ \\
\hline Lares & $\begin{array}{l}\text { 5: Niños de Jesús, Purificación de Nuestra Seńora, la de Asunción de Nuestra Seńora, Apostol Santiago, San Cosme } \\
\text { y San Damián }\end{array}$ \\
\hline Guayllabamba & $\begin{array}{l}\text { 10: (4 Guayllabamba, } 6 \text { Urquillos). Santísimo Sacramento, Purísima Concepción de Nuestra Señora, Nuestro Padre } \\
\text { San Pedro, San Juan Baptista, Santísimo Sacramento, Purísima Concepción de Nuestra Señora, Nuestra Señora de } \\
\text { Monserrate, Benditas Ánimas del Purgatorio }\end{array}$ \\
\hline Ollantaytambo & 6: Santísimo Sacramento, Asunción, San Juan Bautista, Ánimas del Purgatorio, Apóstol Santiago, Santa Rosa \\
\hline Yucay & $\begin{array}{l}\text { 15: (4 cofradías españolas, } 11 \text { indios). Santísimo Sacramento, Purísima Concepción de Nuestra Señora, Ánimas } \\
\text { del Purgatorio, Soledad de Nuestra señora, Santísimo Sacramento, Resurrección, Asunción de Nuestra señora, } \\
\text { Nuestra Seńora de Belén, Natividad de Nuestra Señora, San Joseph, Niños Jesús, San Joan Baptista, Santiago, San } \\
\text { Sebastián, San Juan de Saagún }\end{array}$ \\
\hline Urubamba & $\begin{array}{l}\text { 13: del Señor (españoles), del Señor (indígenas), del Rosario, de las Ánimas, del Niño Jesús, Resurrección, Asunción } \\
\text { de Nuestra Señora, Purísima Consepción de Nuestra Señora, San Juan Bautista, Nuestro Padre San Pedro, San } \\
\text { Bartholomé, Nuestra Señora de la Limpia Concepción }\end{array}$ \\
\hline Maras & $\begin{array}{l}\text { 14: Santísimo Sacramento, Purificación de Nuestra Señora, Purísima Concepción de Nuestra Señora, Natividad de } \\
\text { Nuestra Seńora, Jesús Nazareno, Asumpción de Tiobamba, de las Ánimas, del Nombre de Jesús, San Juan Bautista, } \\
\text { de la Soledad, de la Misericordia, San Sebastián, San Marcelo, Nuestro Padre San Pedro }\end{array}$ \\
\hline Guaraconde & $\begin{array}{l}\text { 9: Santísimo Sacramento, Nińo de Jesús, la Corona de Espinas, Nuestra Señora del Socorro, la de la Concepción, la } \\
\text { de la Purificación, San Martín, San Sebastián, Ánimas del Purgatorio }\end{array}$ \\
\hline Chinchero & $\begin{array}{l}\text { 12: (9 Chinchero, } 3 \text { Omasbamba). Santísmo Sacramento, Santo Cristo de la Coluna, Niño Jesús, de la Concepción, } \\
\text { Asumpción, San Miguel, San Joan Baptista, San Sebastián, Ánimas del Purgatorio, de la Purificación, San Andrés, } \\
\text { Santa María Magdalena }\end{array}$ \\
\hline Quiquijana & $\begin{array}{l}\text { 6: Santísimo Sacramento, Purísima Concepción de Nuestra Señora, Ánimas Benditas del Purgatorio, San Pedro, } \\
\text { San Bartolomé, Nombre de Jesús. }\end{array}$ \\
\hline Zangarará & $\begin{array}{l}\text { 11: (3 Sangarará, } 3 \text { Yanampampa, } 2 \text { Marcaconga, } 3 \text { Acopia) Sanctísimo Sacramento, Nuestra Señora de las Nieves, } \\
\text { Nuestra Seńora de la Candelaria, Niños Jesus, San Juan Baptista, Santa Cathalina, Niño Jesús, San Juan Baptista, } \\
\text { Santisimo sacramento, San Gerónimo }\end{array}$ \\
\hline Pomacanche & $\begin{array}{l}\text { 5: (2 Pomacanche, } 2 \text { Sancta Lucía, } 1 \text { San Juan) Niño de Jesús, Santísimo Sacramento, Niño Jesús, Sancta Lucía, } \\
\text { San Juan Baptista }\end{array}$ \\
\hline Pampamarca & $\begin{array}{l}\text { 6: (2 Pampamarca, } 1 \text { San Juan de la Cruz, } 3 \text { Solimana) Santísimo Sacramento, Asunción, San Juan Baptista, la de } \\
\text { la Purificción, Sancta Bárbara }\end{array}$ \\
\hline Ianaoca & 3: Apóstol Santiago, Dulce Nombre de Jesús, Santísimo Sacramento \\
\hline Checasupa & 4: Santísimo Sacramento, la de la Concepción, San Andrés, Nuestra Señora de la Visitación ${ }^{21}$ \\
\hline
\end{tabular}

21 Pichigua (13), Coporaque (5), Yauri (4), Macarí (5), Coaca (3), Para (¿?), Aparoma (¿?), Sandia (¿?), Azángaro (7), Chupa

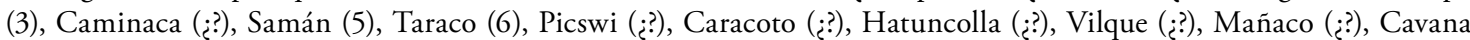
(1), Cavanilla (¿?), Lampa (¿?), Orurillo (6), Aiquire (¿?), Santiago de Popuja, Langui (5), Sicuani (8), Cacha (10), Tinta (11), Checacupe (8). 


\begin{tabular}{|c|c|}
\hline Nuñoa & 2: Santísimo Sacramento, de las Ánimas \\
\hline Aiapata & $\begin{array}{l}\text { 4: (2 Aiapata, } 2 \text { Ollachea). San Salvador, Nuestra Señora de la Candelaria, Nuestra seńora de la Purificación, San } \\
\text { Francisco }\end{array}$ \\
\hline Juliaca & 1: Santísimo Sacramento \\
\hline Pucará & $\begin{array}{l}4 \text { Tiene cinco estancias compuestas, la primera es del Convento de Monjas de Santa Clara de la Ciudad del Cuzco, } \\
\text { que se llama Caco, la segunda de Colque es de Juan Francisco Ramos, la tercera nombrada Acoyani es de el } \\
\text { Bachiller don Andrés de Cartagena Presbítero; la cuarta llamada Calcala es de Juan Gonzales Navarro; la quinta, y } \\
\text { última de Ancoyo de las benditas Ánimas del Purgatorio }\end{array}$ \\
\hline Asillo & $\begin{array}{l}4 \text { Tiene esta Doctrina mil y quatrocientas almas entre indios e indias; y espańoles diez y seis hombres y mujeres } \\
\text { [...] y las demás de la cofradías del Smo. Sacra.to, Nra. Sa. Del Rosario; San Gerónimo, y San Sebastián.-Tiene este } \\
\text { pueblo un hospital confirmado por su Mag.d [sic] }\end{array}$ \\
\hline
\end{tabular}

De esta manera, tal como lo demuestra el cuadro anterior, de todas las visitas realizadas (1674-1687) durante la administración del obispo Mollinedo, todas (salvo 10 unidades territoriales -pueblos, curatos o anexos-) tenían o una cofradía de las Ánimas del Purgatorio, o del Santísimo Sacramento, o ambas. Este panorama es de vital importancia para comprender la función no solo social sino que también simbólica de las cofradías, pues la asignación a un culto u otro no responde solamente a la designación del santo o santa patrona, sino que mucho más importante aún, a narrativas, cristianas y andinas, que se actualizaban constantemente. Así, es posible analizar el valor que pudieron haber tenido, por ejemplo, las cofradías de las Ánimas Benditas o del Purgatorio, pues desde la religiosidad católica el mundo de los difuntos siempre tuvo cierta importancia, aspecto que posee un punto de encuentro bastante fuerte con la religiosidad andina. Asimismo, cabe señalar la importancia de este recuento en términos del valor regional de este tipo de cofradías. A pesar de que parecen haber sido las encargadas de la promoción de "la idea del infierno y la corrección temporal del purgatorio", sus registros históricos han resultado esquivos hasta este momento (Cruz, 2012, p. 728).

Las cofradías de las Ánimas Benditas o del Purgatorio vienen a rescatar el relato de la muerte de Cristo y de los fieles y el tránsito de los difuntos hacia la Gloria y salvación. El punto específico que esta cofradía revive es precisamente el de la purgación completa, espiritual y física, de todos los errores y pecados cometidos por el difunto, espa- cio y tiempo que es gobernado por un riquísimo imaginario sobre los castigos, penas y seres que lo habitan. ${ }^{22}$ Por otra parte, el Santísimo Sacramento presenta igualmente un aspecto extremadamente crítico de encuentro entre ambos tipos de creencias, pues viene a confirmar la presencia física, ya no simbólica, del cuerpo de Cristo en la homilía, gracias al principio de la transubstanciación. Ahora bien, del amplio espectro de cofradías, tanto las Ánimas del Purgatorio como el Santísimo Sacramento tienen su principal desarrollo hacia finales del siglo XVI, alcanzando el auge en el siglo XVII en todo el territorio español y americano, hecho que se debe básicamente a los dictámenes tridentinos (García Baeza, 2003; Vico 2003), y por los datos presentados en la tabla anterior es posible rescatar la "dupla" que se estableció durante el siglo XVII entre ambos tipos de cofradías, pues en aquellos lugares donde no había ninguna (o muy pocas cofradías), se ordenaba la constitución de ambas simultáneamente.

\section{Las cofradías de naturales y el arte en las iglesias}

La pintura mural de las iglesias de los siglos XVI y XVII se encuentra dispuesta, arquitectónicamente, casi por doquier: en el exterior, en la portada y en la capilla abierta; y en el interior, en el presbiterio, arco

22 "La devoción por las almas benditas del Purgatorio se reconoce en conjunto con la existencia y éxito del Purgatorio, proceso que se sitúa entre los siglos XVI y XVIII" (Cruz, 2012, p. 722). 


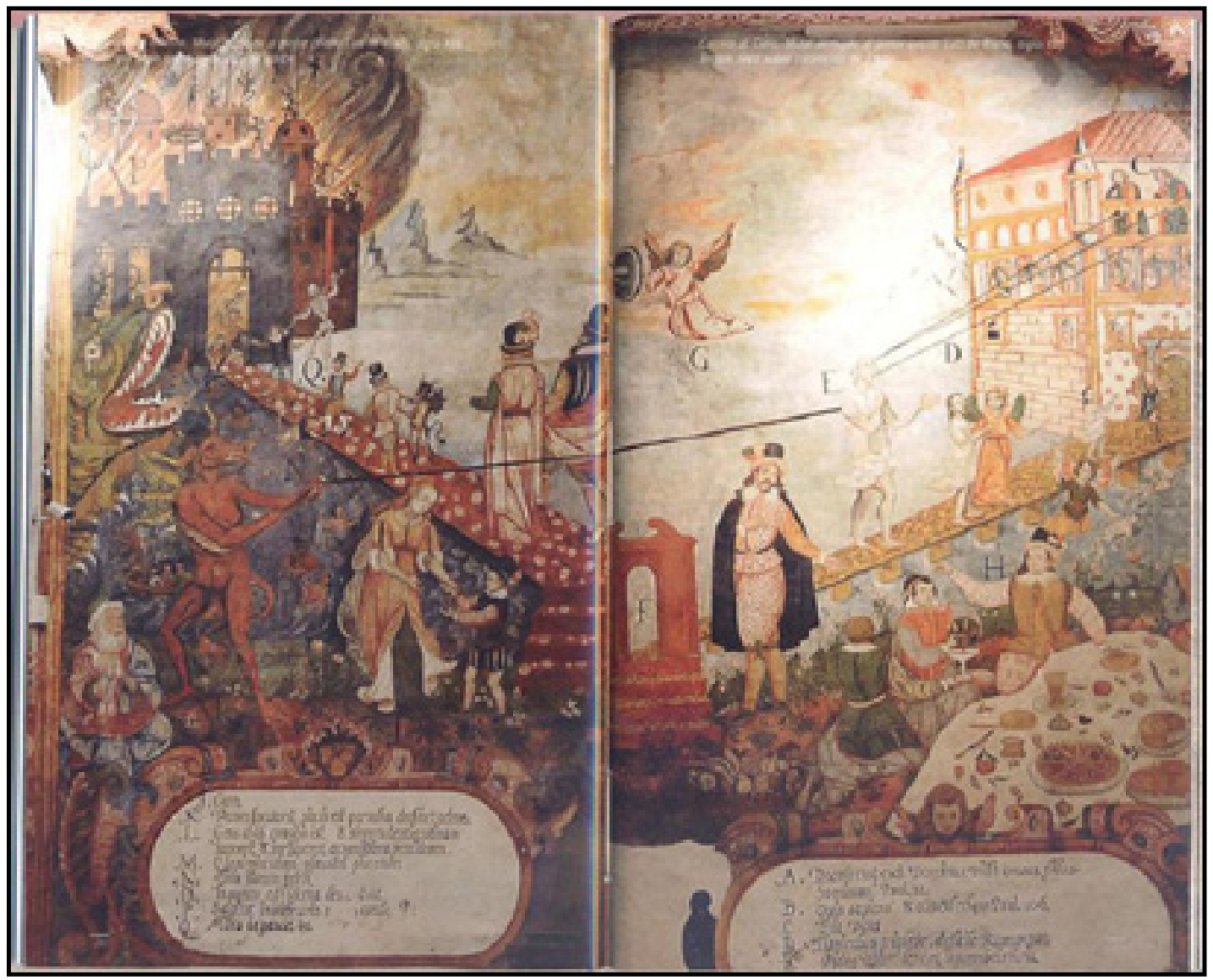

Figura 6. Detalle de mural Camino al cielo, camino al infierno, en iglesia de Andahuaylillas, Cusco.

triunfal, sotacoro y, eventualmente, la nave (tal como es posible apreciar en la Figura 6). Si bien los murales más reconocidos del barroco cusqueño son obras adjudicadas a las grandes figuras de dicho período artístico, para inicios del siglo XVII ya hay en Cusco un importante número de artistas indios y mestizos que habían aprendido en los talleres de maestros durante el siglo XVI, o bien, eran contratados como ayudantes en las distintas labores relacionadas con la elaboración de pinturas y por tanto, incorporaban dichos conocimientos. Algunos de los murales más famosos corresponden a creaciones realizadas después del terremoto de 1650 , aunque en varios casos es imposible adjudicar a ciencia cierta la autoría de las pinturas, puesto que era práctica habitual que los pintores indios no firmasen sus obras o que, debido a los distintos procesos de reconstrucción o de cambio de una a otra orden religiosa, los murales fuesen mo- dificados, retocados o derechamente vueltos a pintar en su totalidad..$^{23}$ (ver Figura 6).

23 Tanto en la Escena de la Anunciación como en Camino al cielo, Camino al infierno podemos notar la existencia de escritura junto con la pintura. En el segundo caso, además, se sigue el patrón de la pintura didáctica según Nadal. Mesa y Gisbert (1982) argumentan que la pintura mural que se encuentra en las iglesias de los siglos XVI y XVII se ubica, en el exterior, en la portada y en la capilla abierta; y en el interior, en el presbiterio, arco triunfal, sotacoro y, eventualmente, la nave. Los investigadores dividen las iglesias en dos grupos (para el período que aquí nos interesa). Dentro del primer grupo, que incluiría las iglesias construidas y pintadas entre 1580 y 1630, se encuentran la de Oropesa, San Jerónimo, Andahuaylillas, Checacupe, Sangarara, Huasac, Urcos y Chinchero, y en términos estilísticos se caracterizan por una fuerte presencia del manierismo. El segundo grupo se caracteriza por una aproximación estilística a la textilería andina, y su período de manufactura es en- 
Los vínculos entre cofradías y pintores en Cusco y sus alrededores fueron constituyendo espacios para la promoción de una imaginería religiosa que se fue fortaleciendo con el desarrollo de los talleres regionales. Recordemos que tempranamente la figura de Francisco de Torres permitió trazar algunas líneas de interés, ya que a pesar de haber sido pintor, también desarrolló su faceta escultórica y doradora, marcando un claro ejemplo de las ocupaciones multifacéticas de los artesanos indígenas durante la Colonia. Como ya advertimos, el terremoto que sufrió la ciudad de Cusco en 1650 tuvo como lamentable consecuencia la pérdida de gran parte del patrimonio artístico y arquitectónico. Ello no obstante trajo un renovado interés por la arquitectura de las iglesias en el afán de reconstruirlas, así como el desarrollo de la pintura. Una parte de este proceso de reconstrucción y embellecimiento de la cuidad fue liderado por el obispo Manuel de Mollinedo, bajo cuya tutela aparecieron las figuras artísticas de Tomás Tuiru Tupac, Basilio Santa Cruz, Marcos Rivera, Martínez de Oviedo, entre otros. A partir de este momento se produce una concatenación de eventos que lleva al gremio de artesanos, cohesionado durante la mayor parte del siglo XVII, a dividirse internamente entre artesanos europeos e indígenas.

tre 1630 y 1700 . Dentro de este grupo encontramos las iglesias de Cay-Cay, Quiquijana, Zurite, Tinta, Huasac, Yanaoca, Canincunca, Pitumarca y Colquepata. Los textos son los siguientes, respectivamente: "SANCTO ADONAI RADEX CLAVIS REX ORIENS”y “ADecado respetix dominis Omnes filios Sonium. Psal.32 / B- Qvis Sapiens Cosiodet Sec Psal. 106 / C- Tria vota / D-Tuniculus Triplex Dificile Rumpitur / E- Vide alia [...] Ler Em [...] Inmen [...] Brismiris [...] Rano [...] Stom [...] Portam / J- Caro[...]n Te / K-Vecors Locutae est, Siquis est Panulvs Aedinet Adme / L- Gens Absaz Concilio Este y Sine Prudentia Utinam Sapadent [...] Intelligent Acno Vistima Providerem / M- Quasi Vinculum Plaustri Peccatum / N- Finis Illorum Inferi / OIn Puncto ad Inferna Descendunt / P- Sagitat Inobsrudis R [...] Corde P[...] / Q- Mors de Pascet [...] O”. Esta pintura mural se encuentra en el muro de ingreso y "flanqueando la puerta de acceso se observan a cada lado, dos escenas del tema evangelizador que muestra al espectador los conceptos del bien y del mal, y de cómo la Iglesia católica los difundía en el primer tercio del siglo XVII, para la conversión de los nativos" (Castillo, Kuon y Aguirre, s/f, p. 34).
Los artistas españoles, indios y mestizos, que se encontraban reunidos bajo un mismo gremio desde 1649 con las ordenanzas de Lima, se ven enfrentados, en 1688, a raíz de una disputa entre los pintores espańoles e indios con motivo de la construcción del arco triunfal para la festividad del Corpus Christi de ese año. Sin embargo, el motivo de fondo sería que los pintores indios eran subcontratados por los artistas espańoles, dándoles tratos poco adecuados y pagándoles malamente por sus trabajos. El enfrentamiento no tuvo más solución que terminar en la separación definitiva de los pintores indios de los españoles. "Este hecho entre los pintores había tenido un antecedente con la Cofradía de San José, es decir, la de los carpinteros, de Cuzco, la cual estaba escindida en dos: la constituida por los retablistas y carpinteros indígenas de la Catedral y la que formaban los oficiales españoles en la iglesia de Santo Domingo" (Pizarro Gómez, 2003, p. 199). Este evento es trascendental, ya que a partir de este momento, libres de las imposiciones del gremio, los artistas indios y mestizos se guían por su propia sensibilidad y trasladan al lienzo su mentalidad y su manera de concebir el mundo. ${ }^{24} \mathrm{~A}$ partir de la separación en 1688 existirán en Cusco dos agrupaciones diferentes de pintores, los españoles unidos a doradores y escultores, que eran alrededor de veinte, y los pintores indios con una cifra incomparablemente mayor. No solo eran grupos étnicamente distintos, sino que

24 "Los pintores indios toman desde ese momento un rumbo diferente, liberándose de las normas del gremio y negándose a dar examen, lo que hace que su arte derive en obras espontáneas que tienden al arte popular. Son decorativas y ricas en color pero relajadas en el dibujo. La primera consecuencia de la separación es el arcaísmo, pues, faltos de información y contacto con las fuentes europeas, los artistas indios se aferran a las fórmulas conocidas que repiten insistentemente. Técnicamente trabajan en los dos planos ya citados, por una parte la pintura 'ordinaria' pobre de color, pues se halla realizada con una gama restringida de pigmentos y la pintura de 'brocateado fino', donde el dorado y la precisión del diseño, así como el dulce colorido, nos muestran esas piezas tan cotizadas, que parecen obra de repujado y donde los valores estéticos distan mucho de ser los occidentales. En lo social, estos pintores indios liberados de las exigencias gremiales están a su vez, poco protegidos viéndose obligados a trabajar para caciques como Sicos, dueños de recua como Rincón y aun para inescrupulosos revendedores quienes comercian con una mano de obra barata y dócil” (Mesa y Gisbert, 1982, p. 23). 


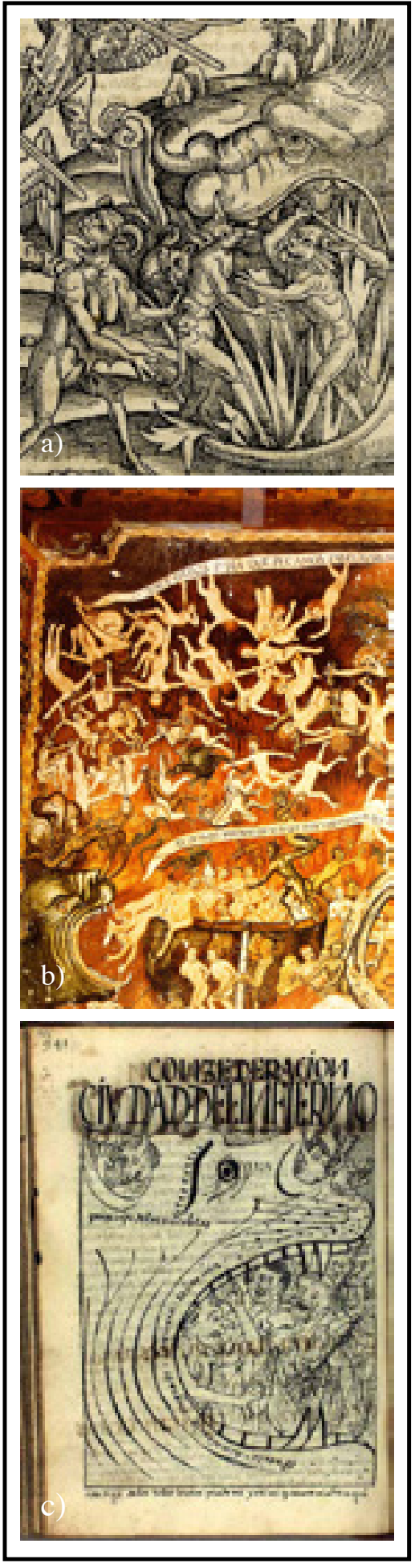

Figura 7 a) Detalle The Coronation of the Virgin, de Hans Franck; b) Detalle Entrada al infierno, iglesia de Andahuaylillas; c) Ciudad del infierno 941

[955], por Guaman Poma. dos estilos diferentes, pues hasta ese momento los lineamientos artísticos eran fijados por los españoles; incluso los pintores indios más importantes del siglo XVII como Quispe Tito o Santa Cruz seguían algunas formas europeas, como consta en las imágenes siguientes (Figura 7).

Para inicios del siglo XVII, ya hay en Cusco un importante número de artistas indios y mestizos que habían aprendido en los talleres de maestros, o bien, eran contratados como ayudantes en las distintas labores relacionadas con la elaboración de pinturas $y$, por tanto, incorporaban dichos conocimientos. Entre los pintores indígenas del siglo XVII encontramos varios exponentes de primera importancia, sin embargo, el más trascendental para el desarrollo cabal del estilo cusqueño es Diego Quispe Tito, que se encuentra activo en Cusco entre 1627 y 1681, dando cuenta de una larga vida de actividad en la que sus numerosas y creativas composiciones serán de gran influencia para otros artistas indígenas hasta el siglo XVIII. ${ }^{25}$ Otro pintor indígena, Lázaro Pardo Lago, por ejemplo, pintó varios cuadros, entre los que destacan Encarnación del Señor y Asunción de la

25 Es en la obra de Quispe Tito que se prefiguran algunas de las características que tendrá la pintura cusqueña en adelante, como cierta libertad en el manejo de la perspectiva, un protagonismo antes desconocido del paisaje y la abundancia de aves en los frondosos árboles que forman parte del mismo. De este maestro, muy importantes son las obras referidas a la serie de doce composiciones sobre la vida de San Juan Bautista que se encuentra en la iglesia de San Sebastián cercana al Cusco y la serie del Zodíaco (Catedral). La reconstrucción de la vida y trabajos de Diego Quispe Tito nos permite proponer la existencia de un taller de pintura que parte con la figura de Quispe Tito y que se abre en las figuras de Melchor Pérez de Holguín, Diego Callaimara, Alonso Yunca, Diego Huallpa, Andrés Juan Túpac (o Juantupa) y Bernabé Nina Inga. Refiriéndose a las asociaciones que realizaban pintores como los que acabamos de mencionar, Mesa y Gisbert señalan que "son los grandes maestros, como Quispe Tito y Santa Cruz, los que aglutinan en torno a su taller y su círculo a los maestros indios que, como discípulos y seguidores, romperán la parcial dependencia que estos artistas tenían respecto a los europeos y criollos. Pintores como Bernabé Nina, los Sinchi Roca y Chihuantito, desde 1680 comienzan a trabajar solos y, a partir de ellos, se inicia la rica vena pictórica de lo mestizo" (Mesa y Gisbert, 1982, p. 172). 
Virgen. ${ }^{26}$ Del trabajo de Basilio Santa $\mathrm{Cruz}^{27}$ se puede deducir al menos que tuvo bajo su tutela a Juan Zapaca Inca (o también Juan Zapata). ${ }^{28}$

26 En 1660 pintó y decoró el retablo de Santa Catalina, labor para la cual contrató la ayuda del pintor oficial Miguel Saqui. Otro de sus ayudantes, Diego Chalco, "oficial dorador", fue contratado "por cuatro meses en noviembre de 1660, 'para trabajar en todo lo que le ordenare dorar y pintar'. La obra de este maestro debe hallarse inmersa en el retablo de la Purificación del Monasterio de Santa Clara que Pardo Lago contrata cuatro días antes y varios de cuyos cuadros aún se conservan en el refectorio del citado monasterio" (Mesa y Gisbert, 1982, p. 173).

27 A diferencia de Quispe Tito, es mucho más apegado a los cánones de la pintura occidental dentro del estilo barroco. Activo en la segunda mitad del siglo XVII, Santa Cruz deja lo mejor de su obra en la Catedral, pues recibe el encargo de decorar los muros del costado del coro y de los brazos del transepto. En el cuadro de la Virgen de Belén, ubicado en el coro, sobresale un retrato del obispo y mecenas Manuel de Mollinedo y Angulo, quien es fundamental para el desarrollo del arte en el virreinato y promotor formidable de la pintura cusqueña. La llegada del obispo Mollinedo al Cusco en 1673 es inseparable del desarrollo e importancia artística que adquiere Santa Cruz, pues fue el principal patrocinador del maestro, encargándole muchas de las obras que hasta hoy se encuentran en las iglesias de Cusco. Mollinedo tenía gran afición por las artes y conocía las corrientes artísticas dominantes en la Europa de su tiempo; es así como llega a la ciudad inca con pinturas de grandes maestros como El Greco, Sebastián de Herrera, Eugenio Caxés, entre otros, cuyas obras influyeron en el desarrollo de la pintura cusqueńa (Mesa y Gisbert, 1982).

28 Sobre los talleres de pintura que operaron hacia finales del siglo XVII, Mesa y Gisbert reseñan que la problemática se debió tornar compleja y angustiosa en la década del ochenta-noventa, cuando los encargos eran mayores y las tensiones se volvieron insostenibles. Si hacemos un análisis sereno del problema, y por lo que hasta ahora sabemos, debemos decir que los encargos a indios y españoles estuvieron equilibrados: en la iglesia de Tinta, en la década del sesenta, aparece contratado Rivera para la serie de San Juan (1664?) y Serrano para la serie de la Virgen (1663); en contrapartida en la misma década, Quispe Tito con sus seguidores llena de cuadros la iglesia de San Sebastián. En San Francisco del Cusco, la serie sobre la vida del santo es pintada por Basilio Santa Cruz, Juan Zapaca Inca y ayudantes, y completada por Marcos de Rivera; en la Catedral del Cusco, Basilio de Santa Cruz parece llevar la parte principal, por lo menos en los ańos 1690-93, y el resto lo realiza Sinchi Roca y ayudantes. En tanto en La Merced, salvo un cuadro de Santa Cruz, el resto lo contratan Rivera,
Ahora, aparte de los talleres donde pintores indígenas tenían cierto grado de protagonismo, la lectura de algunos de los contratos establecidos entre las cofradías y los artistas de la época arroja interesantes luces acerca del rol que estas instituciones tuvieron en el auge artístico y en el asentamiento de los programas iconográficos. Por ejemplo, hacia finales del siglo XVI, en 1583, se concertaba en la ciudad del Cusco un contrato según el cual el maestro se obligaba

[a] hacer un retablo de Nuestra Señora de la Soledad, conforme a una estampa que tiene en su poder y el dicho retablo ha de ser y se ha de pintar en un retablo que el dicho Santangel tiene que lo ha visto Juan Gomez, mayordomo de la Cofradia de la Soledad y Redención de Cautivos, el cual retablo ha de ir pintado al oleo y la guarnición y las dos moldurillas doradas y la cenefa del medio de color [...] (Protocolo 27/779 ff. 1129, AHDC, en Cornejo Bouroncle, 1954, pp. 54-55).

Las indicaciones sobre la ejecución artística podían ser más o menos minuciosas, como lo atestigua el contrato entre el pintor Fernando Inga y el mayordomo de la cofradía de Nuestra Señora de las Mercedes, donde el primero se compromete a pintar y dorar la capilla de Nuestra Señora de la Soledad

[...] según y de la forma e manera que lo tengo concertado con el dicho Gaspar Moreno [...] e yo el dicho Gaspar Moreno Mellado como tal mayordomo de la dicha cofradía y en su nombre acepto este concierto según en el se contiene y me obligo y a los bienes de la dicha cofradía a la paga de lo que se le rresta [...] con las costas de la cobranza e para lo aver por firme obligo los bienes e rrentas de la dicha cofradía y los mios ávidos e por aver [...] (protocolo 719, ff. 64 a 64v. AHDC, en Cornejo Bouroncle, 1951, pp. 295-297). ${ }^{29}$

Gerónimo Málaga y ayudantes (Mesa y Gisbert, 1982, pp. 137-138).

29 Similares son los casos para Lima a fines del siglo XVI. Los pintores Cristóbal Ortega y Diego Rodríguez, en conjunto con Andrés Sánchez, mayordomo de la cofradía de Nuestra Señora de la Visitación, formalizaron pin- 
Del mismo modo, Felipe Sicos, alcalde mayor de la parroquia de San Cristóbal estableció un contrato con un maestro pintor, por lo cual debía prestar servicios para "pintar lienzos chicos i grandes según estampas". Para dicho efecto, se acordó que

\section{[...] Phelipe de Mesa maestro pintor princi-} pal de la parroquia del señor San Christoval de la dicha ciudad del ayllo ingaconas libres en presencia y con asistencia de Don Gerónimo de alegria y Carvajal protector de los naturales de ella y por interpretación de Thomas demolina y perales interprete General de los naturales de ella. Otorgava y otorgó que se consertava y conserto con don Phelipe Sicos alcalde mayor de las ocho parroquias de esta dicha ciudad en esta manera que el dicho don Phelipe de messa maestro pintor se obliga a pintar todos los liensos chicos y grandes que pintare por las estampas que le diere el dicho don Phelipe Sicos y mas le a de dar todas las colores liensos y bastidores y todo lo necesario para las dichas pinturas, $\mathrm{y}$ tan solamente el dicho maestro se obliga a poner su trabajo personal y de todos los liensos que asi se hisieren [...] (Protocolo 368, Notarial, s/ff. AHDC, en Cornejo Bouroncle, 1951, pp. 284-285)

A mediados del siglo XVII, en 1654, Pedro Fernández Inga, de oficio maestro ensamblador, acordó con Antonio Colaco, mayordomo de la cofradía de San Antonio de Padua, realizar un retablo de cedro para la "capilla que tienen en la iglesia de San Francisco" (Protocolo 165/597, ff.59, AHDC, en Cornejo Bouroncle, 1952, p. 84). Igualmente, para 1657 los mayordomos de la cofradía de Nuestro Señor Jesucristo y su Santa Columna y Conversión de San Pedro contrataron a "Juan Quispe, indio, maestro carpintero y ensamblador, para hacer un retablo de madera de aliso y cedro" (Prot. 179/769. Ff. 278v, AHDC, en Cornejo Bouroncle, 1952, p. 89). Años más tarde, en 1661, el licenciado Gaspar Carlos y

tar el retablo de la Catedral. Diego Rodríguez para 1592 recibió como aprendiz del oficio de pintor y dorador a un indígena natural de Chachapoyas proveniente de la encomienda de don Pedro de Vergara (Lévano, 2012).
Zegarra, cura y vicario de la doctrina de Marcapata requirió del maestro Francisco Arias para "pintar en su iglesia y las demás iglesias y capillas de su doctrina, lienzos al óleo y bultos de las imágenes que le diere, pagando por cada pieza 40 pesos corrientes de a ocho reales" (Prot. 196/710. Ff. 289, AHDC, en Cornejo Bouroncle, 1952, p. 92). En 1662 Andrés Chihuantopa y Alonso Nina, indios naturales de la parroquia de Santiago, que se desempeñaban como maestros pintores, formalizaron un acuerdo con $\mathrm{Ga}$ briel Anticusi y otros, mayordomos y priostes de la cofradía de Nuestra Señora de la Caridad, fundada en la iglesia Catedral, para "hacer de pasta pintada y dorada, doce tarjas y en medio el Espíritu Santo, en forma igual al altar de don Pedro Ortega Sotomayor, obispo que fue del Cuzco, por la cantidad de 100 pesos cada uno" (Prot. 197/664. Ff. 1325, AHDC, en Cornejo Bouroncle, 1952, p. 92). En el año 1671 Lorenzo Sánchez de Medina, pintor cusqueño, fue contratado por Joseph Asencio Cuadros y Juan de Rivera Gallegos, mayordomos de la Cofradía del Santísimo Sacramento, fundada en la parroquia del Hospital de Naturales, con el objetivo de "pintar siete lienzos de dos varas y media de largo por dos y cuarto de ancho, de la historia de la institución, conforme a unas estampas que recibe; lienzos que dará acabados con toda perfección, dentro de cinco meses de la fecha, pagándosele por su trabajo, 25 pesos por cada lienzo" (Protocolos 136/679 ff. 1002, AHDC, en Cornejo Bouroncle, 1952, p. 105).

\section{Conclusión}

La evangelización que tuvo lugar en la región andina, específicamente en el Obispado del Cusco, siguió de manera cercana las directrices propuestas por el Concilio de Trento, lo que no la eximió de tener que llevar a cabo importantes adaptaciones que buscaban allanar el camino hacia las almas de los naturales de la zona. Es en este contexto que debe entenderse el desarrollo de las artes pictóricas coloniales asociadas al culto catequético, con especial observación a las pinturas de murales, lienzos y grabados, pues la imaginería demostró desde los albores de la empresa de conquista ideológica una especial idoneidad para la transmisión de los paradigmas cristianos. 
Poco después, los fundamentos conciliares tridentinos fueron apoyados por los del limense, que también incentivó el uso de la imagen como vehículo catequético, enfatizando la reducción de temas a las postrimerías y juicio final. Este programa iconográfico se desarrolló principalmente asociado a las parroquias de naturales de las ciudades de Cusco y de Potosí (Gisbert, 2010), manifestando no solo a quienes estaba dirigido, sino también quienes llevaron a cabo dichas pinturas.

La evidencia expuesta en las páginas precedentes permite establecer el vínculo existente entre las cofradías de naturales y la ejecución de las obras de arte del período colonial, lazo hasta ahora escasamente explorado. Parece contundente la relación, asimismo, entre las cofradías del Santísimo Sacramento y de las Ánimas del Purgatorio con el programa iconográfico de las postrimerías en la zona cusqueña, aunque queda aún por encontrar los contratos que relacionen directamente a ambas cofradías con la ejecución de los murales asociados al programa iconográfico de las postrimerías. En este sentido nos hacemos partícipes del sentir de Normando Cruz cuando lamenta la escasa documentación dejada por estas cofradías también en otros rincones del virreinato del Perú. De la misma manera, se hace perentorio explorar la posible existencia de esta misma tríada (programa iconográfico-cofradía-pintura) en otras zonas donde las postrimerías tuvieron un auge importante, como en la ciudad de Oruro con las iglesias de Curahuara de Carangas, Sorocachi, Andamarca Potosí (San Lorenzo), Puno (Huancané), Lima ${ }^{30}$ (Rapaz) y La Paz (Carabuco, Caquiaviri, Laja, Cohoni, Collana).

Asimismo, se hace imperioso un estudio amplio que vincule el rol que cumplieron las cofradías en la evangelización y en la difusión de los programas iconográficos que esta propugnaba, investigaciones como las que ya comienza a haber en otros secto-

30 Una exploración preliminar arroja un resultado bastante interesante para la ciudad de Lima, donde aparecen colonialmente 199 cofradías del Santísimo Sacramento y 185 de las Ánimas. Las únicas cofradías que se acercan a estos números son la de Copacabana (189) y Purísima Concepción (357), mientras que las demás, por lo general, se encuentran muy por debajo (véase Campos, 2014). res del mismo virreinato (Roselló, 2000; Mancusso, 2007; Castro, 2008; Cruz, 2012, etc.), lo que permitiría establecer las particularidades del fenómeno en la región en estudio así como las características globales del programa de las postrimerías -en su aspecto visual, social e ideológico- en el terruño americano.

\section{Agradecimientos}

Proyecto postdoctoral FONDECYT 3150110: La formación del español andino: Parroquias de indios en los siglos XVI-XVII, Proyecto FONDECYT 1151138 y UTA Mayor 5730-14 y Convenio UTA 2017006337.

\section{Referencias citadas}

Báez Rubí, L. (2005). Mnemosine novohispánica. Retórica e imágenes en el siglo XVI. México: UNAM, Instituto de Investigaciones Estéticas.

Bargellini, C. (2007). La pintura colonial en América Latina. En Revelaciones. Las artes en América Latina, 1492 - 1820 (pp. 324-336). México: Fondo de Cultura Económica.

Bazarte, A. y García, C. (2001). Los costos de la salvación: Las cofradias y la ciudad de México (siglos XVI al XIX), México: Centro de Investigación y Docencia económicas, Instituto Politécnico Nacional, Archivo General de la Nación.

Benítez, M. (1998). Las Cofradias medievales en el Reino de Valencia (1329-1458), Alicante: Publicaciones Alicante.

Campos, F. J. (2014). Catálogo de cofradias del Archivo del Arzobispado de Lima. Lima: Instituto Escurialense de Investigaciones Históricas y Artísticas.

Castillo, M., Kuon, E. y Aguirre, C. (s.f.). San Pedro Apóstol de Andahuaylillas. Guia de visita. Cusco: CCAIJO.

Castro, N. (2008). Y le tuviesen por santo. Caminos de la devoción indígena colonial (Audiencia de Charcas, 1708). Diálogo Andino, 31, 7-29.

Cohen, A. (2011). Las pinturas murales de la iglesia de San Pablo de Cacha (Canchis, Perú). Allpanchis, 77-78, 11-48. 
Cornejo Bouroncle, J. (1952). Arte Cuzqueño. Revista del Archivo Histórico del Cuzco, 3, 66-140.

Cornejo Bouroncle, J. (1953). Arte Cuzqueño. Revista del Archivo Histórico del Cuzco, 4, 176-210.

Cornejo Bouroncle, J. (1954). Arte Cuzqueño. Revista del Archivo Histórico del Cuzco, 5, 49-97.

Cornejo Bouroncle, J. (1951). Arte Cuzqueño. Revista del Archivo Histórico del Cuzco, 2, 270-392.

Cruz, E. (2012). Preocupaciones terrenas en una cofradía. Las Ánimas benditas del purgatorio de Jujuy en el período colonial. Hispania Sacra, LXIV(130), 721-736.

De Esquivel y Navia, D. (1980). Noticias Cronológicas de la gran Ciudad del Cuzco. Tomos I y II. Lima: Fundación Augusto N. Weise.

De la Cruz, A. (1985). Las Cofradias de los negros de Lima. Una institución colonial en evolución. Tesis de Bachillerato defendida en la Pontificia Universidad Católica del Perú, Lima.

Díaz, A., Martínez, P. y Ponce, C. (2014). Cofradías de Arica y Tarapacá en los siglos XVIII y XIX. Indígenas andinos, sistema de cargos religiosos y festividades. Revista de Indias, LXXIV(260), 101-128.

Egoavil. T. (1986). Las Cofradias en Lima, siglos XVII y XVIII. Lima: Universidad Nacional Mayor San Marcos.

Estenssoro, J. (2003). Del Paganismo a la Santidad. La incorporación de los indios del Perú al catolicismo, 1532 1750. Lima: Pontificia Universidad Católica del Perú e IFEA.

Flores Ochoa, J., Kuon, E. y Samanez, R. (1993). Pintura mural en el sur andino. Lima: Banco de Crédito del Perú.

Franck, H. (1510-1514). The coronation of the Virgin (Printed by Matthias Hupfuff) Strasbourg: British Museum.

García, C. (2003). La devoción de Baeza al Santísimo Sacramento en la Edad Moderna. En Religiosidad y ceremonias en torno a la eucaristía, 1, 391-408.

Garland, B. (1994). Las Cofradías en Lima durante la Colonia. Una primera aproximación. En Ramos, G. (Comp.). La venida del Reino. Religión, evangelización y cultura en
América, siglos XVI-XX (pp. 199-228). Cusco: Centro de Estudios Regionales Andinos Bartolomé de Las Casas.

Gisbert, T. (2010). El cielo y el infierno en el mundo virreinal andino. En Entre cielos e infiernos. Memoria del $V$ Encuentro Internacional sobre Barroco. La Paz: Fundación Visión Cultural.

Guaman Poma de Ayala, F. (1615). El primer nueva corónica y buen gobierno. Recuperado de http://www.kb.dk/permalink/2006/poma/info/es/frontpage.htm [consultado 26.08.16]

Guibovich Pérez, P. y Wuffarden, L. E. (2008). Sociedad y gobierno episcopal. Las visitas del obispo Manuel Mollinedo y Angulo 1674-1687. Lima: IFEA - Instituto Riva-Agüero.

Lévano, D. (2012). El mundo imaginado y la religiosidad andina manifestada. El papel social y espiritual de las cofradias en Lima barroca. Madrid: Editorial Académica Española.

López de Ayala, I. (Trad.). (1845 [1564]). El sacrosanto y ecuménico Concilio de Trento. Barcelona: Ramón Martín.

Mancuso, L. (2007). Cofradias mineras: Religiosidad popular en México y Brasil, siglo XVIII. México: El Colegio de México.

Mannheim, B. (2012). Introducción a Juan Pérez Bocanegra (1631). Ritual formulario e institución de curas. Edición facsimilar. Cusco: Facultad de Ciencias Sociales, Universidad Nacional San Antonio Abad del Cusco, xxi-xxxvii.

Martínez C., J. L., y Martínez S., P. (2013). Narraciones andinas coloniales. Oralidad y visualidad en los Andes. Journal de la Société des Américanistes, 99(2), 41-81.

Martínez Sagredo, P. (2014). El castellano y la castellanización de los indigenas del común en el Cuzco colonial (15321700): métodos, espacios y prácticas. Tesis para optar al grado de Doctor en Literatura, Facultad de Filosofía y Humanidades, Universidad de Chile.

Martínez Sagredo, P. (2013). Evangelización andina, educación y castellanización de los indígenas del común. Apuntes sobre el aporte de la compañía de Jesús. Allpanchis, XLIV(81-82), 405-436.

Mesa, J. y Gisbert, T. (1982). Historia de la pintura cuzqueña. Lima: Fundación Augusto N. Wiese. 
Pizarro Gómez, F. (2003). Identidad y mestizaje en el barroco andino. La iconografía. Actas del II Congresso Internacional do Barroco, Universidad de Porto, Porto. Recuperado de http://ler.letras.up.pt/uploads/ficheiros/7511.pdf

Rodríguez G. de Ceballos, A. (1999-2000). Usos y funciones de la imagen religiosa en los virreinatos americanos. En Brown, J. Los siglos de oro en los virreinatos de América (pp. 89-107). Madrid: Museo de América.

Rodríguez Romero, A., y Siracusano, G. (2011). La iconografía de Las Postrimerías: una propuesta de investigación interdisciplinaria. Papeles de Trabajo, 7, 114-128.

Roselló, E. (2000). La cofradía de San Benito Palermo y la integración de negros y mulatos en la ciudad de la Nueva Veracruz en el siglo XVII. En Pastor, M. A. y Mayer, A. (Eds.). Formaciones religiosas en la América Colonial (pp. 229-243). México: Universidad Nacional Autónoma de México.

Valenzuela, J. (2010). Devociones de inmigrantes. Indígenas andinos y plurietnicidad urbana en la conformación de cofradías coloniales (Santiago de Chile, siglo xvii). Historia, 43(1), 203-244.
Vargas Ugarte, R. (1953). Concilios Limenses 1551-1772. Tomo II. Lima: Tipografía Peruana.

Vargas Ugarte, R. (1954). Concilios Limenses 1551-1772. Tomo III. Lima: Imprenta Gil.

Vico, A. (2003). El Santísimo Sacramento como centro de la piedad. En Religiosidad y ceremonias en torno a la eucaristía. Vol. 1 (pp. 447-468).

Villanueva Urteaga, H. (1982). Cuzco 1689. Informes de los párrocos al obispo Mollinedo. Economía y sociedad en el sur andino. Cusco: CERA Bartolomé de Las Casas.

Webster, S. (2014). El arte letrado: Andrés Sánchez Gallque y los primeros pintores en la Audiencia de Quito. En Catálogo de la exposición Andrés Sánchez Gallque y los primeros pintores en la Audiencia de Quito. Museo de Arte Colonial de Quito.

Yates, F. (2005). El arte de la memoria. España: Siruela. 
